\title{
Application of Plant Viruses in Biotechnology, Medicine, and Human Health
}

\author{
Srividhya Venkataraman and Kathleen Hefferon *
}

check for updates

Citation: Venkataraman, S.;

Hefferon, K. Application of Plant

Viruses in Biotechnology, Medicine, and Human Health. Viruses 2021, 13, 1697. https://doi.org/10.3390/ v13091697

Academic Editors: Carla Varanda and Patrick Materatski

Received: 18 December 2020

Accepted: 12 July 2021

Published: 26 August 2021

Publisher's Note: MDPI stays neutral with regard to jurisdictional claims in published maps and institutional affiliations.

Copyright: (c) 2021 by the authors. Licensee MDPI, Basel, Switzerland. This article is an open access article distributed under the terms and conditions of the Creative Commons Attribution (CC BY) license (https:/ / creativecommons.org/licenses/by/ $4.0 /)$.
Department of Cell and Systems Biology, University of Toronto, Toronto, ON M5S 3B2, Canada; byokem@hotmail.com

* Correspondence: kathleen.hefferon@alumni.utoronto.ca

\begin{abstract}
Plant-based nanotechnology programs using virus-like particles (VLPs) and virus nanoparticles (VNPs) are emerging platforms that are increasingly used for a variety of applications in biotechnology and medicine. Tobacco mosaic virus (TMV) and potato virus X (PVX), by virtue of having high aspect ratios, make ideal platforms for drug delivery. TMV and PVX both possess rod-shaped structures and single-stranded RNA genomes encapsidated by their respective capsid proteins and have shown great promise as drug delivery systems. Cowpea mosaic virus (CPMV) has an icosahedral structure, and thus brings unique benefits as a nanoparticle. The uses of these three plant viruses as either nanostructures or expression vectors for high value pharmaceutical proteins such as vaccines and antibodies are discussed extensively in the following review. In addition, the potential uses of geminiviruses in medical biotechnology are explored. The uses of these expression vectors in plant biotechnology applications are also discussed. Finally, in this review, we project future prospects for plant viruses in the fields of medicine, human health, prophylaxis, and therapy of human diseases.
\end{abstract}

Keywords: expression vectors; aspect ratio; VLPs; VNPs; TMV; PVX; CPMV; geminivirus; cancer; theranostics; CRISPR-cas9

\section{Introduction}

Over the past few years, plant viruses have increased in visibility for a wide range of applications in biotechnology. Plant viruses are highly suitable for production of vaccines as they are recognized by the innate immune system through the pathogen associated molecular pattern (PAMP) receptors [1] while being non-pathogenic to mammals. Plant viruses can elicit both cell-mediated immunity [2,3] and a humoral immune response when delivered through mucosal [4] or parenteral [5] routes.

Plant virus genomes have been engineered to express heterologous open reading frames. For example, deconstructed virus vectors (Figure 1) were generated first using TMV [6,7] and PVX [8], of which the former was produced commercially by Icon Genetics as the magniCON vector [6]. Using this TMV magnifection technology, full immunoglobulin IgG was produced in under 2 weeks at high yields ( $4.8 \mathrm{~g} / \mathrm{kg}$ fresh weight tissue) [9].

Plant viruses have also been developed as VLPs and VNPs in order to present them as epitope display systems for vaccine production and as scaffolds for the conjugation of drugs or molecules used in diagnostics (Figure 2). VNPs and VLPs based on plant viruses are favorable because they are non-pathogenic to humans, and hence preclude any unwanted side effects/contamination. VNPs are nanoparticle formulations based on viruses that can be employed as building blocks for novel nanomaterials exhibiting a variety of molecular characteristics [10]. VNPs are self-assembling highly symmetrical systems that are dynamic, polyvalent, and monodisperse. They are advantageous due to reasons such as their robustness and ability to be generated in short time periods while serving as programmable molecular scaffolds. Additionally, VNPs are superior to synthetic nanomaterials by virtue of being biocompatible and biodegradable. Several self-assembly 
mechanisms have been adopted to encapsulate ligands such as small chemical modifiers, peptides, proteins, or even additional nanoparticles into the VNPs for which a wide range of conjugation chemistries have been employed [11,12]. These include strategies such as encapsulation, mineralization, chemical bioconjugation, and genetic engineering.

A. TMV
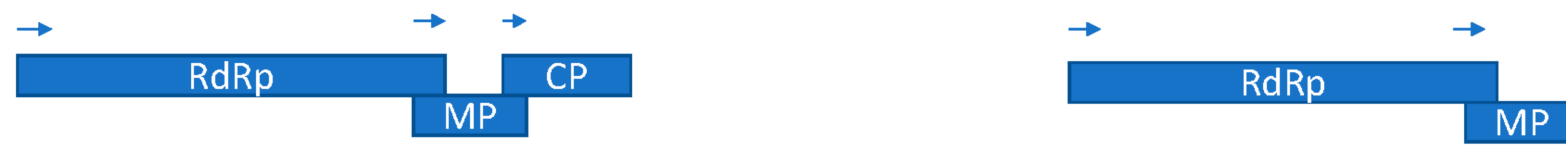

GOI

Full virus

Deconstructed virus

B. PVX
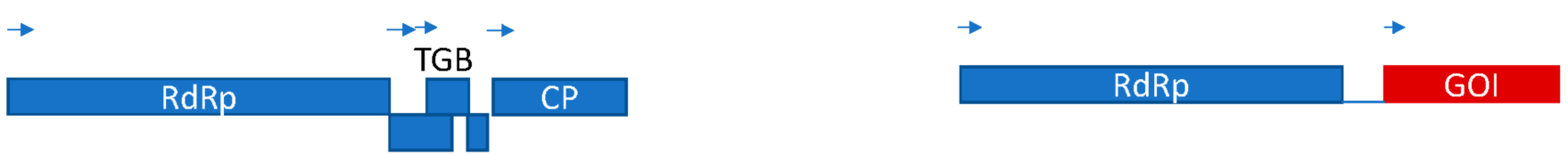

Figure 1. Schematic diagrams of full-length genome vs. deconstructed vectors of TMV (A) and PVX (B). RdRp, RNAdependent RNA polymerase; MP, movement protein; $\mathrm{CP}$, coat protein; GOI, gene of interest; TGB, triple gene block.

A.
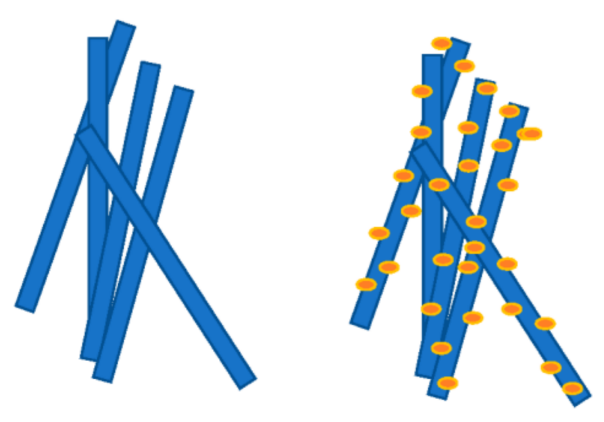

C.

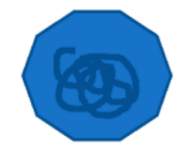

(i)

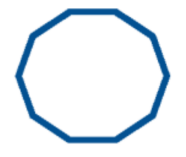

(ii)
B.
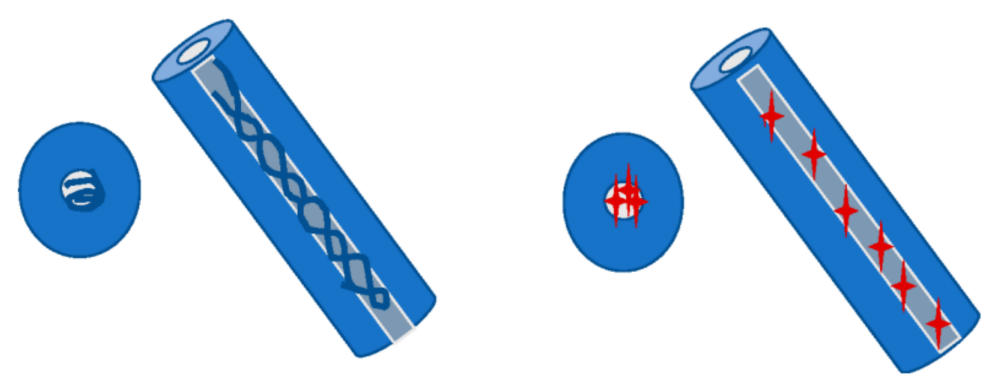

Figure 2. Schematic diagrams of TMV and CPMV wild-type virus vs. virus nanoparticles: (A) WT TMV (left hand side) and TMV nanoparticle (right hand side) displaying drug moieties conjugated to the surface of virus particle; (B) WT TMV (left hand side) containing viral RNA and TMV nanoparticle (right hand side), in this case RNA genome is replaced with drug moieties on the interior of the virus particle; (C) (i) CPMV intact virion, (ii) empty virus-like particle (eVLP), (iii) drug moieties conjugated to surface of eVLP, (iv) with drug moieties captured within eVLP. 
VLPs are a subset of the VNPs but bereft of any nucleic acid genome, thus, making them noninfectious. VLPs are powerful vaccine candidates as they simulate the conformations of native viruses, utilizing their intrinsic immunogenicity while not compromising their safety. They accomplish this by having no viral genome, and therefore being unable to replicate [13]. Hence, VLPs have become popular as subunit vaccines while several plant viruses have been used to generate VNPs. VLPs evoke effectual immune responses as they are readily internalized by the antigen presenting cells (APCs) and are ideal platforms for antigen processing and epitope presentation to the immune system. Additionally, VLPs are increasingly used in cancer immunotherapy wherein their inherent ability to stimulate immune reactions can be employed to prime the tumor microenvironment towards launching antitumor immunity. VLPs occur as repetitive, multivalent molecular scaffolds by virtue of being composed of their capsid proteins in multiple copies that facilitate multivalent presentation of antigens. Therefore, VLP vaccines afford superior immunogenicity as compared with antigens in their soluble states. Additionally, plant viral VLPs and VNPs possess inherent adjuvant properties dispensing with the use of additional adjuvants to evoke strong immune responses.

Knowledge and insight into the molecular structure of TMV [14] and PVX [15], for example, have enabled their use for several applications as biocatalysts [16], fluorescent markers [17], nanoparticles for in vivo imaging [18], nanoparticles for biologics purification [19], vaccines [20-22], and assembly units for memory devices [23]. Plant viral VNPs serve toward a variety of applications such as immunotherapy [24], chemotherapy [25], vaccines [26], gene delivery [27], and plant virus-assisted sensors [28].

The following review describes many of the uses of plant viruses in biotechnology, with examples based on TMV, PVX, CPMV, and geminiviruses. In the last section, we conclude with a future projection of the significance of plant viruses in the fields of medicine and engineering.

\section{Molecular Characteristics of TMV Advantageous for Biotechnological Use}

TMV was initially characterized in the 19th century and has since become a paradigm for our current perspective on the morphogenesis of self-assembling viral particle structures [29]. TMV is the most well-studied plant virus, and it is also the most important plant virus both scientifically and economically [30,31]. In recent times, this knowledge has been translated toward the generation of novel compounds and structures that could be used in nanotechnology and medicine. TMV can be easily produced and purified in bulk amounts, and therefore has become of tremendous importance in molecular biology and virology [32]. TMV has been used to detect translational enhancers for the augmented expression of heterologous genes $[33,34]$, and for the design of effective vectors for virusinduced gene silencing and transient expression in plant systems [35], as well as for creating virus-resistant plant lines [36,37].

TMV is also simple and well-characterized with respect to particle structure and genome organization. Thus, it is well suited as a highly amenable experimental system for different applications. The rod-shaped virus particle measures $300 \mathrm{~nm}$ in length and $18 \mathrm{~nm}$ in diameter, and contains a $6.7 \mathrm{~kb}$ viral RNA genome that is encapsidated by 2130 identical copies of the capsid protein assembled in a helical arrangement. The crystal structure of the 158 amino acid capsid protein has been determined [38]. The genomic RNA contains a stretch of 432 nucleotide bases that forms the origin-of-assembly sequence (OAS) sufficient for viral assembly [39]. At neutral $\mathrm{pH}$ and without its RNA, the coat protein (CP) assembles itself into an $18 \mathrm{~nm}$ double disk, a 20S aggregate or nano-ring containing two layers of 17 CP molecules which can serve as a nanoscale scaffold. The amino acid sequence of the $\mathrm{CP}$ has many accessible regions for chemical modifications both at the inner and outer surfaces [30]. TMV can also assemble into spherical nanoparticles of 100-800 nm, in the absence of its RNA genome, by thermal processing [40]. Moreover, the TMV RNA genome can self-assemble with its purified CP in vitro to generate infectious virus particles [41], in 
addition to its ability to self-assemble in vivo. Therefore, TMV has become a model system for RNA-protein recognition.

Different strategies can be used to modify TMV, such as the modification of the interior or exterior surface of the capsid through genetic engineering, chemical conjugation, or a combination of both processes. The interaction and transport of heterologous cargo within the virus inner cavity or generation of multivalent structures by particle integration have thus been adopted. The conformation of the TMV CP facilitates the insertion of foreign peptides at both its $\mathrm{N}$ - and C-termini. In addition to this, the loop formed from $\mathrm{CP}$ amino acids 59-66 can be used towards surface display of foreign peptides on intact virions or on $\mathrm{CP}$ assemblies [42].

\section{The Use of Genetically Engineered TMV in Biochemistry, Nanotechnology, and Plant Biotechnology}

Table 1 illustrates some examples of plant viral expression vectors derived from TMV [43-48], CPMV [49-51], PVX [52], and bean yellow dwarf virus (BeYDV) [53] for generation of foreign proteins.

Table 1. Examples of plant viruses used as expression vectors for foreign proteins.

\begin{tabular}{ll}
\hline Recombinant Protein or Vaccine or VLP & Viral Vector \\
\hline Cholera toxin b subunit & TMV [43] \\
\hline $\begin{array}{l}\text { Human anti-non-Hodgkin's lymphoma single-chain Fv } \\
\text { (scFv) immunoglobulins }\end{array}$ & Hybrid TMV and odontoglossum ringspot virus (ORSV) [44] \\
\hline Rice a-amylase & Hybrid TMV and tomato mosaic virus (ToMV) [45] \\
\hline Assembled full-size monoclonal antibody & Combination of non-competing viral vectors TMV and PVX [46] \\
\hline Human growth hormone & $\begin{array}{l}\text { Hybrid crucifer-infecting TMV (cr-TMV) and turnip } \\
\text { vein-clearing virus (TVCV) [47] }\end{array}$ \\
\hline Plant-produced VLP developed for drug delivery & TMV [48] \\
\hline Plant-produced chimaeric virus vaccine for influenza virus & TMV [21] \\
\hline Assembled full-size monoclonal antibody & CPMV [49] \\
\hline $\begin{array}{l}\text { Plant-produced chimaeric virus vaccine for human rhinovirus } \\
\text { 14 and human immunodeficiency virus }\end{array}$ & CPMV [50] \\
\hline Plant-produced VLP developed for encapsulation of metals & CPMV [51] \\
\hline Plant-produced chimaeric virus vaccine for hepatitis C virus & PVX [52] \\
\hline Hepatitis B core Norwalk virus capsid protein (NVCP) & BeYDV [53] \\
\hline
\end{tabular}

(Adapted from Ibrahim et al., 2019 [54]).

The location of C-terminus of the TMV CP on the exterior surface of assembled TMV virions makes it the most used site for insertion of foreign peptides. Table 2 presents some examples of the plant viruses (TMV [55-57], PVX [58], and CPMV [59,60]) used as drug delivery systems and the respective regions within their coat proteins that are amenable to genetic modifications.

Table 2. Examples of plant viruses used in drug delivery systems.

\begin{tabular}{cccc}
\hline Virus & Symmetry & Family & Locations within the CP Amenable to Genetic Modification \\
\hline TMV & Rod-like & Tombusviridae & Threonine 104/158, serine 123, N/C-terminal of coat protein [55-57] \\
PVX & Rod-like & Potexviridae & N-terminal of coat protein [58] \\
CPMV & Icosahedral & Comoviridae & $\beta B-\beta C$ loop of the small subunit/ $\beta E-\beta F$ loop of the large subunit [59,60] \\
\hline \multicolumn{4}{r}{} \\
\hline
\end{tabular}


TMV particles have been exploited for active enzyme display, with wide-ranging uses in biodetection, sensor development, medicine, and enzymatic conversion. Enzymes such as penicillinase [62,63], horseradish peroxidase [64], and glucose oxidase [65] have been expressed on the TMV surface, as TMV exhibits a strong stabilizing effect on these enzymes. TMV adapter rods have been incorporated on sensor surfaces, which have facilitated bioaffinity-derived presentation of streptavidin conjugates of the above enzymes at surface densities that are not attainable on supports free of TMV. Enhanced reusability and augmented target detection ranges of these high-performance TMV-based biosensors have been reported and present great promise for multiple applications.

TMV membranes have been engineered that could be recruited as tissue engineering frameworks by sequentially altered layering of two TMV variants with different charges. Recently, these TMV-based carrier templates have been used to prepare surfaces that promote cellular attachment and differentiation [66-68].

Some cells have been cultivated on TMV-covered culture supports and peptide ligands have been presented in a spatially defined manner over nanometric scales. Arginineglycine-aspartic acid peptide associated TMV layers have been used for osteogenesis of stem cells from bone marrow $[67,68]$. TMV has been employed as a carrier for peptide motifs and is capable of cell-binding that simulates extracellular matrix proteins. TMV-derived nanorod fibers synthesized from complexation with electrospun composite polymers have been used to generate mats for better handling [69].

Transgenic plants expressing TMV CP were generated by Powell Abel et al. (1986) [37]. These plants showed resistance to TMV challenge and, as a result, initiated the theory of "capsid protein-induced resistance" [70]. TMV has also been used to engineer virusinduced gene silencing (VIGS) systems for Colletotrichum acutatum, a phytopathogenic fungus which proved to efficiently assemble virus particles inside hyphal cells [71].

\section{The Use of TMV in Medicine, Cancer, Imaging, and Theranostics}

TMV disks have a flat and round morphology that yields a high aspect ratio. TMV particles, by virtue of their flexuous rod-like structures, marginate toward blood vessel walls, enhancing the likelihood of invading diseased areas of the body, while accumulating inside tumor tissues [61,72]. In contrast to their spherical equivalents, the helical virus derived VLPs and VNPs transit more efficiently through tissues and membranes [73]. As compared with VLPs, VNPs are more effective because their RNA genome cargo functions as a ruler to define the length of the nucleoprotein-virus complex. In addition, the surface characteristics of these viruses can be altered by means of genetic or chemical approaches without compromising virus structural integrity. Consequentially, the positions of functional units such as drugs, contrast agents, or targeting ligands can be spatially controlled which enables the engineering of multifunctional systems that harbor different combinations of these moieties [74].

Molecular imaging is an emerging biomedical field which facilitates the visualization, identification, and evaluation of biological mechanisms in vivo. Some of these imaging technologies include magnetic resonance imaging (MRI), computed tomography (CT), positron emission tomography (PET), and optical imaging, which enable the monitoring of molecular and cellular processes in normal and diseased conditions in living subjects. Ideally, a given molecular imaging technique should readily afford optimal signal-to-noise ratios within the target site while minimizing toxicity [13].

VLPs are more beneficial for molecular imaging technologies than synthetic nanoparticles, due to their short half-life in circulation and their low retention times, which thus reduce probable side effects [10]. Furthermore, VLPs can be developed to carry a wide array of contrast agents and fluorescent labels, as they can be modified with antibodies, peptides, and aptamers to enable enhanced targeting to specific tissues and cells.

TMV has been successfully used for imaging, targeting atherosclerosis, and thrombosis [75]. Cargo mRNA encoding the green fluorescent protein (GFP) was encapsulated within TMV, which when administered into mice, elicited an immune response against 
GFP. This provided a proof-of-concept that this technology can be utilized for vaccine development [76]. TMV has also been engineered to display the iLOV protein, which acts as a fluorescent probe [77]. TMV has also been used in theranostics (drugs and/or techniques combined to both diagnose and treat medical conditions), for enabling photoacoustic imaging and MRI capabilities to photothermal therapy (PTT) treatment.

Table 3a presents some examples of the use of the engineered TMV for treating diseases, while Table $3 \mathrm{~b}$ shows a list of studies wherein TMV has been used for cancer treatment. Table $3 \mathrm{c}$ presents examples of studies using TMV in theranostic applications.

Table 3. Applications of TMV in biotechnology and medicine: (a) Applications of TMV in medicine; (b) applications of TMV in cancer treatment; (c) applications of TMV in theranostics.

\section{(a) Applications of TMV in medicine}

\section{Engineered Modifications}

The extreme C-terminus of the TMV CP fused to the

11 amino acid epitope of the foot and mouth disease virus (FMDV) VP1 protein

\section{Effects}

\section{Reference}

This nanoparticle protected animals against

$$
\text { FMDV challenge }
$$

Peptides from the coronavirus murine hepatitis virus spike protein displayed on the surface of TMV particles

Increased antibody titers and protected mice against murine hepatitis virus challenge

An epitope from Pseudomonas aeruginosa outer

membrane protein $\mathrm{F}$ fused to the $\mathrm{C}$-terminus of the TMV CP

The influenza virus M2e epitope displayed by fusion near the $\mathrm{C}$-terminus of the TMV CP

Demonstrated immunity to Pseudomonas aeruginosa

Afforded protective anti-influenza immune response in mice

Functioned efficiently equivalent to free tPA and

TMV conjugated to the thrombolytic tissue plasminogen activator tPA enhanced safety profile as shown by diminished average bleeding times and therefore applicable for cardiovascular therapy

\section{(b) Applications of TMV in cancer treatment}

\begin{tabular}{|c|c|c|}
\hline Engineered Modifications & Effects & Reference \\
\hline $\begin{array}{l}\text { TMV employed to display a weakly immunogenic } \\
\text { tumor-associated carbohydrate antigen, the Tn } \\
\text { antigen (GalNAc- } \alpha-O-S e r / T h r)\end{array}$ & $\begin{array}{c}\text { Potent immune responses were observed when the Tn } \\
\text { antigen was conjugated to Tyr } 139 \text { of TMV }\end{array}$ & [82] \\
\hline $\begin{array}{l}\text { TMV CP used as nanocarrier for a highly hydrophobic, } \\
\text { insoluble peptide that binds to the neuropilin (NRP1) } \\
\text { receptor transmembrane domain in cancer cells }\end{array}$ & $\begin{array}{c}\text { Shown to be anti-angiogenic by reducing cancer cell } \\
\text { growth and migration }\end{array}$ & [30] \\
\hline Doxorubicin (DOX) loaded onto TMV disks & $\begin{array}{l}\text { Increased rates of survival of mice bearing } \\
\text { intracranial glioblastoma }\end{array}$ & [83] \\
\hline DOX loaded onto TMV VNPs coated with albumin & Antitumor effects & [84] \\
\hline $\begin{array}{c}\text { Cisplatin and phenanthriplatin loaded into the cavity of } \\
\text { TMV by formation of stable covalent adduct or by } \\
\text { charge-based reaction }\end{array}$ & $\begin{array}{l}\text { Enhanced absorption by cancer cells and } \\
\text { improved cytotoxicity }\end{array}$ & {$[85,86]$} \\
\hline $\begin{array}{l}\text { TMV VNPs loaded with cisplatin modified using lactose } \\
\text { and mannose moieties on their external surface }\end{array}$ & $\begin{array}{l}\text { This construction assisted the VNP's recognition by the } \\
\text { asialoglycoprotein receptor that is present on cell } \\
\text { membranes and demonstrated augmented cytotoxicity } \\
\text { in cancer cell lines }\end{array}$ & [87] \\
\hline $\begin{array}{l}\text { Modification of the TMV coat protein with a molecular } \\
\text { fluorous ponytail incorporated at specific sites which } \\
\text { resulted in self-assembly of the virus into } \\
\text { spherical VNPs }\end{array}$ & $\begin{array}{c}\text { These spherical VNP's conferred greater stability of for } \\
\text { the cisplatin-VNP complexes formed via } \\
\text { metal-ligated coordination }\end{array}$ & [88] \\
\hline
\end{tabular}


Table 3. Cont.

\section{(b) Applications of TMV in cancer treatment}

\begin{tabular}{ccc}
\hline Engineered Modifications & Effects & Reference \\
\hline $\begin{array}{c}\text { Mitoxanthrone (MTO) loaded onto TMV VNPs by a } \\
\text { charge-driven mechanism }\end{array}$ & Increased antitumor effects in mice \\
\hline $\begin{array}{c}\text { Antimitotic drug, valine-citrulline monomethyl } \\
\text { auristatin E loaded onto external surface of TMV VNPs }\end{array}$ & $\begin{array}{c}\text { Effective targeting and cytotoxicity in non-Hodgkin's } \\
\text { lymphoma cell line, Karpas 299; internal entry of TMV } \\
\text { VNPs into endolysosomal components accompanied by } \\
\text { protease-encoded release of the drug }\end{array}$ \\
\hline $\begin{array}{c}\text { [90] } \\
\text { Transacting activation transduction (TAT) peptide fused } \\
\text { to the external surface of TMV }\end{array}$ & $\begin{array}{c}\text { The engineered TAT-tagged TMV was internalized; this } \\
\text { delivered RNA silencing in nude mice hepatocellular } \\
\text { carcinomatumors upon intravenous and } \\
\text { intratumoral delivery }\end{array}$ \\
[91]
\end{tabular}

Zn-EpPor (5-(4-ethynylphenyl)-10,15,20-tris(4methylpyridin-4-ium-1-yl)porphyrin-zinc(II) triiodide), a photosensitizer drug loaded onto the interior of the TMV particles

Zn-Por+3 loaded TMV conjugated to F3 peptide
Demonstrated high stability and shelf-life; drug was released into endolysosomes and showed augmented cell-killing efficiency

Targeted the nucleolin shuttle protein overexpressed on Hela cells; drug accumulated on cell membranes along with increased cell-killing efficiency likely due to disruption of the cell membrane through light activation followed by drug release and cellular uptake

(c) Applications of TMV in theranostics

\section{Engineered Modifications}

A near infrared fluorescent (NIR) dye as well as a peptide targeting S100A9 (a myeloid-related protein 14

present in atherosclerotic lesions and a molecular marker for acute myocardial infarctions) were conjugated to TMV

A TMV-MOF (metal-organic framework) hybrid nanoparticle engineered

A Cy5-encapsulated TMV coated with zeolitic imidazolate framework-8 (Cy5-TMV@ZIF)

Gd-dodecane tetraacetic acid (Gd-DOTA) loaded onto TMV particles altered to target the vascular cell adhesion molecule, VCAM-1

Packing of a dysprosium (Dy3+) complex within the interior cavity of TMV

\footnotetext{
A metal-free paramagnetic nitroxide organic radical contrast agent (ORCA) loaded onto TMV particles to generate electron paramagnetic resonance and MRI probes towards the detection of superoxide
}

\section{Effects}

Reference

These targeted TMV particles were able to identify atherosclerotic lesions in apolipoprotein E-deficient (ApoE-/-) mice upon intravenous injection, showing that TMV can be used as a platform to detect at-risk lesions

Increased retention of the TMV VNPs observed in mice

Improved the fluorescence retention time by 2.5 times more than that of the Cy5-TMV alone; this TMV@ZIF was recalcitrant to harsh conditions and proved to be highly stable and non-toxic

Facilitated the sensitive identification and depiction of atherosclerotic plaques in ApoE-/- mice, using low doses of the contrast agent wherein the augmented relaxivity and slower tumbling of the Gd-DOTA coupled with the TMV carrier improved the signal-to-noise ratio; also, this coupling afforded greater sensitivity of imaging, allowing $40 \times$ decrease in Gd dose in comparison with the standard clinical doses

Enhanced T2 relaxivity towards MRI; this enabled NIR fluorescent dye delivery, which facilitated dual optical-MR imaging. The exterior surface of TMV was labeled with an Asp-Gly-Glu-Ala peptide that enabled target specificity to integrin $\alpha 2 \beta 1$ molecules on prostate cancer cells

This augmented in vitro $r 1$ and $\mathrm{r} 2$ relaxivities and these probes worked as both T1 as well as T2 contrast agents, facilitating their suitability for preclinical and clinical 
Table 3. Cont.

(c) Applications of TMV in theranostics

\section{Engineered Modifications}

TMV conjugated to a derivative of the aminoxyl radical

TEMPO (tetramethylpiperidin-1-oxyl, coined

Compound 6) by means of a copper catalyzed azide-alkyne cyclo-addition reaction

TMV nanorods loaded with Gd and coated with polydopamine (PDA)

\section{Effects}

Reference

Subsequent interaction with cucurbit [8] uril (CB [8]) generated an aminoxyl-based ORCA (semitroxane) that was silent for MRI; the r1 (relaxivity) values for TMV-6 emulated that of Gd-DOTA

The PDA enhanced the MRI properties and provided

PDA contrast, while simultaneously facilitating photothermal therapy (PTT); strong in vitro NIR absorption was observed along with increased photothermal conversion efficiency, compared to that of gold nanocages [97] and nanorods [98]; also, these VNPs demonstrated potent efficiency with lowered

cytotoxicity in treating $4 \mathrm{~T} 1$ breast and PC-3 prostate cancer cells in vitro

\section{Molecular Characteristics of PVX Advantageous for Biotechnological Use}

PVX is a single-stranded, positive-sense RNA virus with a flexuous rod-like morphology. The PVX genome is 6430 bases in length [101] and contains a $5^{\prime}$ cap structure and $3^{\prime}$ poly-A tail. There are five open reading frames (ORFs) encoding the ORF1 replicase protein for viral replication, the ORF 2,3, and 4 triple gene block (TGB) proteins which mediate virus movement and the ORF5 capsid protein for encapsidation and cell-to-cell movement. Protein overexpression systems based on plant viruses are more economical and easier to implement as compared with stable transformation which is more laborious and could take protracted lengths of time [102], whereas infecting plants with genetically engineered viruses directly or through Agrobacterium-mediated infiltration enables easy, rapid, highly efficient transient expression of heterologous proteins. Particularly, the sequence between the TGB and the CP can be modified to clone and express foreign genes $[8,103,104]$.

\section{PVX as an Expression Vector and Repurposing PVX for Use in Medicine, Cancer, and Theranostics}

PVX has been widely explored as an expression vector for several biopharmaceutical applications such as for antigenic epitopes displayed on the virus outer surface, as well as for expressing full-length and fusion proteins [105]. Virus-derived biocatalysts have been generated using filamentous PVX that was integrated with the enzyme lipase [16]. The major advantage of this scaffold is the ability of the PVX-lipase complex to self-replicate, unlike the equivalent synthetic systems. Such enzymes can be positioned in or on the virus capsid, thus, spatially combining several different enzymes into specific groups that can simulate metabolic cascades.

Of note is the engineering of PVX to serve various biomedical purposes. Uhde-Holzem et al. (2016) [106] reported genetically altered PVX which displayed Staphylococcus aureus protein A fragments on its surface, and proved to be easily functionalized with IgG to be used in biosensing plant viruses [107]. PVX has also been widely used in biotechnology, disease diagnostics, development of vaccines/antibodies against infectious diseases, as well as cancer research and treatment. The CP of PVX is not capable of forming VLPs on its own $[108,109]$. PVX nanoparticles have been shown to inhibit tumor growth in both cell lines and animal models [110]. They are increasingly being used for immunotherapy of tumor microenvironments.

PVX-based VLPs and VNPs are ideal tools in molecular imaging and unlike synthetic nanoparticles, they have limited half-lives in circulation as well as diminished retention times, thereby, decreasing the chances of unwanted side effects. Additional studies have reported that PVX has been conjugated to fluorescent reporters that could be applied towards theranostics, nanomedicine, and in vivo imaging [111]. The small fluorescent iLOV 
protein was expressed on PVX through genetic engineering, and the resultant engineered PVX served as a fluorescent probe which could be of potential use in vivo imaging. Shukla et al. (2018) [112] reportedly produced PVX VNPs that displayed mCherry or GFP on their $\mathrm{N}$-termini in $N$. benthamiana plants. Significantly, fluorescent PVX could successfully be used for in vivo particle tracking in an HT-29 murine model, for in vitro imaging of HT-29 cells, and for tracing viral infection within plants.

In plant systems, PVX has been used in the identification of pathogenicity determinants of various viruses, fungi, and bacteria (Table $4 \mathrm{a}$ ). Table $4 \mathrm{~b}$ presents examples of studies using PVX for diagnosis, prophylaxis, and therapy of infectious diseases, while Table 4c shows instances where PVX has been successfully used in the treatment of cancer.

Table 4. Applications of PVX in biotechnology and medicine: (a) Applications of PVX in identifying pathogenicity determinants and in VIGS; (b) applications of PVX in the diagnosis, prophylaxis and therapy of infectious diseases; (c) applications of PVX in cancer.

(a) Applications of PVX in identifying pathogenicity determinants and in VIGS Engineered Modifications Effects Reference

PVX used as an expression vector for the production of V2, C1, and C4 proteins of a novel monopartite begomovirus, the Ageratum leaf curl Sichuan virus in N. benthamiana

Deletion and mutational analysis of the $\mathrm{C} 4$ protein using this PVX-derived vector showed that $\mathrm{C} 4$ is the major pathogenicity determinant which impacted symptom expression and virus accumulation

Phytophthora sojae virulence effector Avh148 expressed in plants using a PVX-based vector and a virus-induced virulence effector (VIVE) assay to detect putative effectors encoded by various plant pathogens

Grapevine leafroll-associated virus 2 (GLRaV-2) encodes a p24 polypeptide (a suppressor of RNA-silencing) that was expressed in a PVX-based vector
This PVX-Avh148 vector infected plants with strong viral symptoms and led to elevated levels of Avh148 effector and viral RNA accumulation; Avh148 was

Tomato torrado virus (ToTV) capsid protein subunits Vp23, Vp26, and Vp35 expressed transiently from a PVX-derived vector in Solanum lycopersicum

PVX has been developed as a VIGS vector in potatoes wherein VIGS mediates silencing of endogenous plant genes, thus helping to investigate the functions of the silenced genes found to be essential for full pathogenic virulence; this VIVE assay could detect putative effectors encoded by various plant pathogens including even unculturable pathogens using this PVX-based expression vector

p24 causes systemic necrosis in N. benthamiana wherein a cytoplasmic $\mathrm{Zn2+-binding} \mathrm{protein,} \mathrm{NbRAR1} \mathrm{is}$ involved and the symptoms are characteristic of a hypersensitive response; the essential role of p24 in GLRaV-2 pathogenesis was elucidated using the PVX expression vector wherein both silencing suppression and p24 self-interaction are critical for the pathogenic activity of p24

Of these, Vp26 protein was shown to be the necrosis and pathogenicity determinant responsible for severe systemic necrosis of the plants accompanied by increased ribonuclease and oxidative activities

This caused the silencing of the endogenous phytoene desaturase gene in potato plants which led to

characteristic photobleaching symptoms in the leaves by

interference of the carotenoid biosynthetic pathway

(b) Applications of PVX in the diagnosis, prophylaxis, and therapy of infectious diseases Engineered Modifications

The scFv-TM43-E10 and scFv-Fc-TM43-E10 antibody derivatives specific for the recognition of the Salmonella typhimurium Omp D protein expressed in a deconstructed PVX vector deficient for virus movement Effects

These PVX vector-based antibodies exhibited similar antigen-binding specificities as that of their mammalian/microbial cell-generated counterparts and were able to successfully recognize the $S$. typhimurium Omp D antigen; therefore showed great promise as new diagnostic tools for the detection of S. typhimurium infection

The presence of antibodies specific to the SARS-CoV N protein could be detected in SARS-CoV patient sera using the plant-derived $\mathrm{N}$ protein

\section{Reference}

The Severe Acute Respiratory Syndrome Coronavirus (SARS-CoV) N and M proteins expressed using PVX 
Table 4. Cont.

(b) Applications of PVX in the diagnosis, prophylaxis, and therapy of infectious diseases

Engineered Modifications

The M2e peptide of H1N1 Influenza virus was fused to bacterial flagellin to augment immunogenicity and then expressed in a PVX vector
Effects

Reference

The yield of the fusion protein was as high as $30 \%$ of the total soluble protein and mice inoculated with the PVX-derived protein exhibited protection against Influenza virus infection
The hyper variable region 1 (HVR-1) epitope of

Hepatitis C Virus (HCV) expressed in a PVX Vector and administered parenterally
This elicited IgG immune response and the PVX-HVR1 epitope reacted positively with the serum of chronic $\mathrm{HCV}$ patients

A second capsid protein promoter of PVX used to express a chimaeric protein derived from fusion of the

$\mathrm{HCV}$ core antigen with the hepatitis $\mathrm{B}$ virus (HBV) surface antigen (HBsAg)
This PVX-based polytopic HCVpc-HBsAg construct could be a potential plant-derived $\mathrm{HCV}$ vaccine
(c).Applications of PVX in cancer

\begin{tabular}{|c|c|c|}
\hline Engineered Modifications & Effects & Reference \\
\hline $\begin{array}{l}\text { PVX used as an expression vector for Mambalgin-1, a } \\
\text { peptide that functions as a potent analgesic by } \\
\text { obstructing acid-sensing ion channels (ASIC) in nerve } \\
\text { cells wherein the ASIC is involved in the growth and } \\
\text { proliferation of cancer cells }\end{array}$ & $\begin{array}{c}\text { This resulted in the production of Mambalgin-1 which } \\
\text { exhibited cytotoxicity towards nervous (SH-SY5Y) } \\
\text { cancer cells, inhibited ASIC channels and potentiated } \\
\text { anticancer effects }\end{array}$ & [122] \\
\hline $\begin{array}{l}\text { Monoclonal antibodies of Herceptin or Trastuzumab } \\
\text { loaded onto PVX nanofilaments }\end{array}$ & $\begin{array}{l}\text { This successfully induced apoptosis in breast cancer } \\
\text { cell lines }\end{array}$ & [123] \\
\hline $\begin{array}{l}\text { PVX used as an expression vector for a mutant form of } \\
\text { the HPV16 E7 oncoprotein, by fusing it with lichenase }\end{array}$ & $\begin{array}{l}\text { This elicited protection against tumor progression in } \\
\text { mice by inducing robust cytotoxic T-cell response }\end{array}$ & [124] \\
\hline The filamentous PVX used to deliver DOX & $\begin{array}{l}\text { These DOX-loaded PVX VNPs greatly diminished the } \\
\text { growth of tumors in athymic mice harboring breast } \\
\text { cancer xenografts }\end{array}$ & [125] \\
\hline PVX-DOX combination & $\begin{array}{c}\text { Prolonged mouse survival and stimulated } \\
\text { chemokine/cytokine levels in mouse intradermal } \\
\text { melanoma models }\end{array}$ & [126] \\
\hline $\begin{array}{l}\text { PVX used to display tumor necrosis factor-related } \\
\text { apoptosis inducing ligand (TRAIL) }\end{array}$ & $\begin{array}{l}\text { Multivalent display of TRAIL enabled increased } \\
\text { recruitment and stimulation of death receptors } \\
\text { expressed on cancer cell lines and successfully } \\
\text { suppressed tumor growth in mice breast cancer models }\end{array}$ & [127] \\
\hline $\begin{array}{c}\text { PVX conjugated to an idiotypic (Id) tumor-associated } \\
\text { antigen (TAA) recombinant through a } \\
\text { biotin/streptavidin linker }\end{array}$ & $\begin{array}{l}\text { This elicited a } 7 \text { times higher anti-Id IgG response as } \\
\text { compared with Id alone in a mouse B-cell lymphoma } \\
\text { model; IFN- } \alpha \text { and IL-12 were induced; also TLR7 was } \\
\text { found to be essential for viral RNA recognition }\end{array}$ & [128] \\
\hline
\end{tabular}

\section{Molecular Characteristics of CPMV Advantageous for Biotechnological Applications}

CPMV is the type member of the genus Comovirus, composed of two separately encapsidated positive-strand RNAs. RNA-1 is capable of independent replication in plant cells; however, RNA-2 (encoding the viral movement and structural proteins) depends on RNA-1 for its replication. CPMV virions are icosahedral in shape and are comprised of 60 copies each of a large (L) and a small (S) coat protein [129].

\section{Applications of Comoviruses CPMV and Cowpea Chlorotic Mottle Virus (CCMV) in Medical Biotechnology and Cancer}

CPMV has been developed as an autonomously replicating virus vector for the expression of either peptides or polypeptides in plants (Table 5). Examples of CPMV used as an epitope presentation system include epitopes from the outer membrane (OM) protein $\mathrm{F}$ 
of Pseudomonas aeruginosa which were shown to protect mice against bacterial challenge, and an epitope expressing the 30 amino acid D2 domain of the fibronectin-binding protein (FnBP) from Staphylococcus aureus, which has been shown to be able to protect rats against endocarditis [130].

In addition to the use of CPMV to present peptides, replicating and non-replicating expression vectors based on CPMV have been developed [131]. The non-replicating expression system is based on a disabled version of RNA-2 of CPMV. A gene of interest is positioned between the $5^{\prime}$ leader sequence and $3^{\prime}$ untranslated region (UTR) of RNA-2, and the vector is introduced to the plant via Agrobacterium-mediated transient transformation [50]. By deleting an in-frame initiation codon located upstream of the main translation initiation site of RNA-2, a massive increase in foreign protein accumulation has been observed. This CPMV non-replicating system generated high quality purified anti-HIV-1 antibody in plants [132]. The vector has also been used to express influenza vaccine proteins.

Meshcheriakova et al. (2017) compared the differences between empty virus-like particles (eVLPs) of CPMV and intact virus containing its RNA genome, for their potential use as nanoparticles [133]. eVLPs are noninfectious and could be loaded with heterologous material, which has increased the number of possible applications for CPMV-based particles. In addition to this, they have distinct yet overlapping immunostimulatory effects resulting from virus RNA in wild-type particles, and therefore can be used for different immunotherapeutic strategies [134].

As described for TMV, CPMV has been explored for its potential to block cancer [135]. Steinmetz et al. (2011) found that CPMV nanoparticles could bind to vimentin, a protein found on the surface of most cells [136]. Vimentin is upregulated during tumor progression, making it an attractive target for cancer therapy. The fact that surface vimentin expression correlated with CPMV uptake in this study demonstrated the ability of CPMV to detect invasive cancer cells. Soon after this discovery, Lizotte et al. (2016) found that inhaled CPMV nanoparticles could be rapidly taken up by lung cancer cells in a mouse model and activated neutrophils in the tumor microenvironment to initiate an antitumor immune response [137]. CPMV nanoparticles also demonstrated antitumor immunity in ovarian, colon, and breast tumor models in mice.

Patel et al. (2018) used CPMV nanoparticles in conjunction with radiotherapy to delay ovarian tumor growth in a mouse model [138]. The treatment was able to result in an increase in tumor infiltrating lymphocytes (TILs), suggesting that this combined treatment could act as a future in situ tumor vaccine. Further studies by Wang and Steinmetz (2019) found that a protein known as CD47, which is widely expressed on tumor cells, prevents the action of T cells and phagocytic cells. The authors used a combination therapy of CD47blocking antibodies and CPMV nanoparticles to act synergistically and elicit an antitumor immune response [139]. The same research group also used low doses of cyclophosphamide (CPA) and CPMV nanoparticles as a combination therapy to successfully reduce mouse tumors in vivo [140].

Recently, Albakri et al. (2019) explored how CPMV particles could activate human monocytes, dendritic cells (DCs), and macrophages [141]. Monocytes, upon incubation with CPMV in vitro, released the chemokines CXCL10, MIP- $1 \alpha$, and MIP-1 $\beta$ into cell culture supernatants. Dendritic cells and monocyte-derived macrophages also were activated after incubation with CPMV. The authors found that activation was part of SYK signaling. Shukla et al. (2020) were able to demonstrate that CPMV outperformed many other types of virus-like particles, and therefore was a particularly strong immune stimulant [142].

Plant VLPs based on CCMV have been employed to deliver mRNA. For example, CCMV was used to successfully deliver enhanced yellow fluorescent protein (EYFP) mRNA to mammalian BHK-21 cells, using transfection with lipofectamine. In this case, the mRNA was successfully delivered and released from the VLPs into the cytoplasm of the BHK21 cells, facilitating EYFP expression [27]. Furthermore, CCMV can be used to deliver 
mRNA vaccines, and a proof of concept has been demonstrated with a variety of reporter genes [143].

There are other examples of how icosahedral VLPs can be utilized in medicine. For example, CCMV can be disassembled and reassembled to encapsulate CpG ODNs (oligodeoxynucleotides). CpG ODNs are ligands of the toll-like receptor 9 (TLR9). Upon activation, TLR9 has the capability to induce macrophages. The CpG loaded CCMV VLPs showed significantly enhanced uptake by tumor associated macrophages and inhibited the growth of solid CT26 colon cancer and B16F10 melanoma tumors in Balb/c mice via the macrophage activation [144].

As another example, encapsulated drug-activating enzymes within plant VLPs such as CCMV can be utilized for therapeutic purposes [145]. Cytochrome P450 family enzymes can convert chemotherapeutic prodrugs into an active format. Using plant VLPs to encapsulate these enzymes can reduce side effects while increasing retention and targeting to the tumor site $[25,146]$. CCMV has been used, for example, to encapsulate bacterial cytochrome, CYPBM3, to activate the prodrugs into activated forms of tamoxifen and resveratrol.

\section{Molecular Features of Geminiviruses Advantageous for Biotechnological Use}

Plant viruses with ssDNA genomes offer an exceptional alternative format for expression vector design. These plant viruses tend to have small genomes that can readily incorporate open reading frames of unrestricted sizes. They replicate using a rolling circle mechanism and can express genes of interest at extremely high levels; they also infect a broad range of different plant varieties. Geminivirus constructs, for example, require only the virus origin of replication, the gene of interest, and the replication-associated protein (Rep) gene provided in cis or trans format for potential expression in a wide range of plant families $[147,148]$. Geminiviruses are considered unique for their twinned capsid morphology. Although they are transmitted in the wild by insects, they are readily amenable to genetic engineering and can be introduced easily into plants in a laboratory setting.

\section{The Use of Geminiviruses in Biotechnology and Medicine}

Bean yellow dwarf virus (BeYDV) is a geminivirus frequently used for expression of pharmaceutical proteins. BeYDV has recently been used to produce norovirus, HIV, HPV, and hepatitis B virus subunit vaccines, monoclonal antibodies to West Nile virus and Ebola virus, as well as earthworm-derived Lumbrokinase (PI239), used to dissolve fibrin and blood clots $[149,150]$. Besides using higher plants such as tobacco as hosts, geminiviruses have also been used to express proteins in algae [151]. In this case, a microalgae-based system known as Algevir was utilized to produce Ebola virus vaccine protein as well as the highly immunogenic B subunit of the heat-labile Escherichia coli enterotoxin. The authors generated a yield of $1.25 \mathrm{mg} / \mathrm{g}$ fresh biomass $(6 \mathrm{mg} / \mathrm{L}$ of culture), within 3 days after transformation.

More examples of the use of geminiviruses for pharmaceutical production include the expression of plant-made recombinant immune complex (RIC) vaccines [152,153]. In one instance, a bio-better vaccine toward Zika virus (ZIKV) was established. The antigen fusion site ZE3 on the RIC platform was altered to accommodate an N-terminal fusion to the IgG heavy chain (N-RIC) with an improvement of $40 \%$ in RIC expression. This construct produced a strong antibody titer that correlated with neutralization of the Zika virus. Moreover, when these RICs were co-delivered with plant-produced hepatitis B core $(\mathrm{HBc})$ virus-like particles (VLP) displaying ZE3, there was a five-fold greater antibody titer $(>1,000,000)$ that more strongly neutralized ZIKV than using either RICs or VLPs alone, in the absence of adjuvant and after only two doses [154].

In another recent study, a variety of plant-made human IgG1 fusion vaccine candidates were examined using Zika virus (ZIKV) envelope domain III (ZE3) as a model antigen. These fusion constructs were altered to make RICs and generated using geminivirus vectors in plants which had their glycosylation pathways altered to make the plant more humanized in its glycan profile. The results of this study were the generation of a 
vaccine candidate at $1.5 \mathrm{mg}$ IgG fusion per g leaf fresh weight that generated high titers of antibodies specific for Zika virus [155].

Future directions for use of geminivirus expression vectors follow the blossoming new field of genome editing, with this expression vector carrying CRISPR/Cas9 machinery to enable precise gene editing through homologous recombination [156].

Table 5. Medical applications of comovirus and geminivirus vectors.

\begin{tabular}{llc}
\hline \multicolumn{1}{c}{ Virus } & \multicolumn{1}{c}{ Application } & References \\
\hline Comovirus CPMV & Delays tumor growth using combination therapy & {$[137,138]$} \\
\hline & CPMV and cyclosposphamide & {$[140]$} \\
\hline & Activation of monocytes, dendritic cells, macrophages & {$[141]$} \\
\hline Comovirus CCMV & mRNA vaccine delivery & {$[143]$} \\
\hline & $\begin{array}{l}\text { Encapsulate CpG oligonucleotides, activated } \\
\text { macrophages and inhibit growth }\end{array}$ & {$[144]$} \\
\hline & $\begin{array}{l}\text { Encapsulate drug-activating enymes to reduce side } \\
\text { effects, increase targeting to tumor site }\end{array}$ & {$[145,146]$} \\
\hline Geminivirus BeYDV & Vaccines and monoclonal antibodies & {$[149]$} \\
\hline & Monoclonal antibodies to West Nile Virus, Ebola Virus & {$[149]$} \\
\hline & RIC vaccines to ZIKV & {$[154,155]$} \\
\hline
\end{tabular}

\section{Viral Expression Vectors and the CRISPR/Cas9 Technology}

The agricultural industry has been greatly burdened by infections due to plant viruses and several genetic engineering techniques have been applied to confront plant viral infections. Since the turn of the century, RNA interference has been used effectively for this purpose. In a reported pioneering investigation by Zhang et al. (2018), FnCas9 from Francisella novicida and its guide RNA were used to target the RNA genome of TMV and cucumber mosaic virus (CMV) to engineer virus resistance [157]. Three sites of the TMV genome were targeted which inhibited virus accumulation by $40-80 \%$. Additionally, it was found that the FnCas9 bound the RNA genome, but did not cleave it, thus, limiting the chances of the emergence of viral escape mutants and facilitating durable resistance towards virus control in the long term.

Ariga et al. (2020) reported the use of a PVX vector expressing the cas9 gene and single-guide RNA for highly effective targeted mutagenesis in the model system, N. benthamiana [158]. The virus vector was introduced through Agrobacterium transformation that enabled transgene-free gene editing. On the one hand, this coupled with high level expression by amplification of the viral RNA, wherein the PVX can accommodate the large size of the Cas9 gene, is of great applicability in precise editing of the plant genome. On the other hand, other viruses such as the TMV, beet necrotic yellow vein virus, and the tobacco rattle virus cannot accommodate the Cas9 gene due to their size limitations and are known to work only with the Cas9 applied in trans. Deconstructed geminiviruses have been used to express Cas9 successfully, however, such deconstructed forms are not infectious.

One of the most significant antiviral mechanisms of plants is RNA silencing. This is executed through the essential function of the small RNA guided Argonaute proteins which act as agents of viral restriction. One of these proteins is AGO2 which has been proven to be involved in antiviral responses in the host Arabidopsis thaliana. In a study by Ludman et al. (2017), the role of AGO2 in conferring antiviral immunity was explored using Nicotiana benthamiana as the host plant [159]. In this investigation, the CRISPR/Cas9 technology was used to inactivate the AGO2 gene which plays an important role in the immune responses of the plant against PVX and other plant viruses. 


\section{Conclusions}

During the 1980s, the brome mosaic virus (BMV) and the cauliflower mosaic virus (CaMV) were genetically engineered as the first RNA and DNA plant virus vectors, respectively, to express bacterial genes $[160,161]$. Since then, several vectors based on plant viruses have been designed as efficient tools for the expression of recombinant proteins and to advance genomic research. Thus far, many plant viruses have been recruited as delivery vectors for several purposes. These include viruses infecting dicotyledonous plants such as potexviruses [8,162-164], tobamoviruses [165,166], furovirus [167], potyvirus [168-172], geminiviruses [171], comoviruses [172,173], Necrovirus [174], and Caulimovirus [161]. Further, viruses such as Foxtail mosaic virus [175], barley stripe mosaic virus [176-178], wheat streak mosaic virus [179] and soil-borne wheat mosaic virus [167] capable of infecting monocotyledonous plants have been repurposed as expression vectors. Plant viral expression vectors are increasingly being used in basic and applied research requiring the expression of pharmaceutical peptides, antibodies, and other functional complex heterologous proteins. Furthermore, these vectors have been used in functional genomics applications such as virus-based miRNA expression, VIGS, identification of virulence effectors, and virus-mediated genome editing. This review discusses the use of the most popular plant viruses namely the TMV, PVX, CPMV, and geminiviruses for biotechnological purposes, medicine, and human health. While this is not by any means exhaustive considering the wealth of recent and older literature in this area, it addresses some of the major achievements in the use of these viruses as expression vectors.

In the current review, we highlight the use of plant virus based VLPs and VNPs as diagnostic and therapeutic agents for biotechnological and biomedical applications such as VIGs, identification of virulence effectors of plant pathogens, vaccines against cancer and infectious diseases, theranostics and nanocarriers for imaging modalities. VNPs and VLPs play a major role in the future of nanotechnology and nanomedicines. Viruses and VNPs are natural carriers of nucleic acid molecules which protect and transport their cargo, and this is the major property used for drug delivery. Through a combination of chemistries and by attachment of a wide range of functional groups, drug cargo can be encapsulated, infused, conjugated, or absorbed to the exterior and interior surfaces of their coat protein interfaces [180]. This affords molecular flexibility towards protection of cargo with proteinaceous matrices, reversible binding of active molecules, and specific targeting to the sites of action. VNPs are advantageous as natural delivery carriers because of their structural uniformity, water solubility, biocompatibility, ease of functionalization, and high uptake efficacy [181]. Nanosized cages afford ideal approaches for imaging and drug delivery while conferring high stability, cell-targeting, cell penetrability, and appropriate pharmacokinetics. In addition, VNPs do not show tissue tropisms, and therefore can be employed for targeting and binding cell surface receptors, crossing membranes and penetrating the nucleus [182].

The structures of several viruses are known at atomic resolution enabling modifications with spatial selectivity in a precise manner. By genetic engineering, the VLPs can be formulated to obtain new structures having predictable interactions with biological systems]. VLPs can be engineered to display on their surface functional groups such as ligands for targeting, epitopes, imaging dyes, and drug payloads. The VLPs by virtue of their size and shape facilitate vascular transport, active cellular uptake, and molecular interactions. VLPs can tolerate harsh environments while being biocompatible. In addition, high doses of VLPs are mostly well tolerated and the VLPs are completely and rapidly cleared by proteolytic degradation to enable diminished side effects. Moreover, the characteristic ability of the VLPs to self-assemble coupled with novel molecular design using chemical biology technologies enable the production of functionalized hybrid VLP nanomaterials. The field of VNP- and VLP-based technologies for drug delivery applications continues to evolve with several candidates in clinical trials that should lead to advanced therapeutics, in the near future. In the future, it is very much likely that more plant viruses would be genetically engineered and repurposed for further use in biotechnology and medicine. 
Author Contributions: Both S.V. and K.H. contributed equally to writing this manuscript. All authors have read and agreed to the published version of the manuscript.

Funding: This research received no external funding.

Data Availability Statement: Not applicable.

Conflicts of Interest: The authors declare no conflict of interest.

\section{References}

1. Acosta-Ramírez, E.; Pérez-Flores, R.; Majeau, N.; Pastelin-Palacios, R.; Gil-Cruz, C.; Ramírez-Saldaña, M.; Manjarrez-Orduño, N.; Cervantes-Barragan, L.; Santos-Argumedo, L.; Flores-Romo, L.; et al. Translating innate response into long-lasting antibody response by the intrinsic antigen-adjuvant properties of papaya mosaic virus. Immunology 2008, 124, 186-197. [CrossRef] [PubMed]

2. Yusibov, V.; Mett, V.; Davidson, C.; Musiychuk, K.; Gilliam, S.; Farese, A.; MacVittie, T.; Mann, D. Peptide-based candidate vaccine against respiratory syncytial virus. Vaccine 2005, 23, 2261-2265. [CrossRef] [PubMed]

3. Kemnade, J.O.; Seethammagari, M.; Collinson-Pautz, M.; Kaur, H.; Spencer, D.M.; McCormick, A.A. Tobacco mosaic virus efficiently targets DC uptake, activation and antigen-specific T cell responses in vivo. Vaccine 2014, 32, 4228-4233. [CrossRef] [PubMed]

4. Brennan, F.R.; Bellaby, T.; Helliwell, S.M.; Jones, T.D.; Kamstrup, S.; Dalsgaard, K.; Flock, J.-I.; Hamilton, W.D.O. Chimeric plant virus particles administered nasally or orally induce systemic and mucosal immune responses in mice. J. Virol. 1999, 73, 930-938. [CrossRef] [PubMed]

5. Brennan, F.; Jones, T.; Longstaff, M.; Chapman, S.; Bellaby, T.; Smith, H.; Xu, F.; Hamilton, W.; Flock, J.-I. Immunogenicity of peptides derived from a fibronectin-binding protein of S. aureus expressed on two different plant viruses. Vaccine 1999, 17, 1846-1857. [CrossRef]

6. Gleba, Y.; Klimyuk, V.; Marillonnet, S. Magnifection-A new platform for expressing recombinant vaccines in plants. Vaccine 2005, 23, 2042-2048. [CrossRef]

7. Lindbo, J.A. TRBO: A High-Efficiency Tobacco Mosaic Virus RNA-Based Overexpression Vector. Plant Physiol. 2007, 145, 1232-1240. [CrossRef]

8. Chapman, S.; Kavanagh, T.; Baulcombe, D. Potato virus $X$ as a vector for gene expression in plants. Plant J. $1992,2,549-557$.

9. Bendandi, M.; Marillonnet, S.; Kandzia, R.; Thieme, F.; Nickstadt, A.; Herz, S.; Fröde, R.; Inogés, S.; de Cerio, A.L.-D.; Soria, E.; et al. Rapid, high-yield production in plants of individualized idiotype vaccines for non-Hodgkin's lymphoma. Ann. Oncol. 2010, 21, 2420-2427. [CrossRef] [PubMed]

10. Steinmetz, N.F. Viral nanoparticles as platforms for next-generation therapeutics and imaging devices. Nanomedicine 2010, 6, 634-641. [CrossRef]

11. Young, M.; Debbie, W.; Uchida, M.; Douglas, T. Plant Viruses as Biotemplates for Materials and Their Use in Nanotechnology. Annu. Rev. Phytopathol. 2008, 46, 361-384. [CrossRef]

12. Steinmetz, N.F.; Evans, D.J. Utilisation of plant viruses in bionanotechnology. Org. Biomol. Chem. 2007, 5, 2891-2902. [CrossRef]

13. Chung, Y.H.; Cai, H.; Steinmetz, N.F. Viral nanoparticles for drug delivery, imaging, immunotherapy, and theranostic applications. Adv. Drug Deliv. Rev. 2020, 156, 214-235. [CrossRef] [PubMed]

14. Namba, K.; Pattanayek, R.; Stubbs, G. Visualization of protein-nucleic acid interactions in a virus: Refined structure of intact tobacco mosaic virus at $2.9 \AA$ resolution by X-ray fiber diffraction. J. Mol. Biol. 1989, 208, 307-325. [CrossRef]

15. Parker, L.; Kendall, A.; Stubbs, G. Surface features of potato virus X from fiber diffraction. Virology 2002, 300, 291-295. [CrossRef]

16. Carette, N.; Engelkamp, H.; Akpa, E.; Pierre, S.J.; Cameron, N.R.; Christianen, P.C.M.; Maan, J.C.; Thies, J.C.; Weberskirch, R.; Rowan, A.E.; et al. A virus-based biocatalyst. Nat. Nanotechnol. 2007, 2, 226-229. [CrossRef]

17. Yi, H.; Nisar, S.; Lee, S.-Y.; Powers, M.A.; Bentley, W.E.; Payne, G.F.; Ghodssi, R.; Rubloff, G.W.; Harris, M.T.; Culver, J.N. Patterned Assembly of Genetically Modified Viral Nanotemplates via Nucleic Acid Hybridization. Nano Lett. 2005, 5, 1931-1936. [CrossRef]

18. Niehl, A.; Appaix, F.; Boscá, S.; Van Der Sanden, B.; Nicoud, J.-F.; Bolze, F.; Heinlein, M. Fluorescent Tobacco mosaic virus-Derived Bio-Nanoparticles for Intravital Two-Photon Imaging. Front. Plant Sci. 2016, 6, 1244. [CrossRef]

19. Werner, S.; Marillonnet, S.; Hause, G.; Klimyuk, V.; Gleba, Y. Immunoabsorbent nanoparticles based on a tobamovirus displaying protein A. Proc. Natl. Acad. Sci. USA 2006, 103, 17678-17683. [CrossRef] [PubMed]

20. Smolenska, L.; Roberts, I.M.; Learmonth, D.; Porter, A.J.; Harris, W.J.; Wilson, T.; Cruz, S.S. Production of a functional single chain antibody attached to the surface of a plant virus. FEBS Lett. 1998, 441, 379-382. [CrossRef]

21. Petukhova, N.; Gasanova, T.; Stepanova, L.; Rusova, O.; Potapchuk, M.; Korotkov, A.; Skurat, E.; Tsybalova, L.; Kiselev, O.; Ivanov, P.; et al. Immunogenicity and Protective Efficacy of Candidate Universal Influenza A Nanovaccines Produced in Plants by Tobacco Mosaic Virus-based Vectors. Curr. Pharm. Des. 2013, 19, 5587-5600. [CrossRef]

22. Thérien, A.; Bédard, M.; Carignan, D.; Rioux, G.; Gauthier-Landry, L.; Laliberté-Gagné, M.-È.; Bolduc, M.; Savard, P.; Leclerc, D. A versatile papaya mosaic virus (PapMV) vaccine platform based on sortase-mediated antigen coupling. J. Nanobiotechnol. 2017, 15, 54. [CrossRef]

23. Tseng, R.J.; Tsai, C.; Ma, L.; Ouyang, J.; Ozkan, C.S.; Yang, Y. Digital memory device based on tobacco mosaic virus conjugated with nanoparticles. Nat. Nanotechnol. 2006, 1, 72-77. [CrossRef] [PubMed] 
24. Venuti, A.; Curzio, G.; Mariani, L.; Paolini, F. Immunotherapy of HPV-associated cancer: DNA/plant-derived vaccines and new orthotopic mouse models. Cancer Immunol. Immunother. 2015, 64, 1329-1338. [CrossRef] [PubMed]

25. Sánchez-Sánchez, L.; Cadena-Nava, R.D.; Palomares, L.A.; Ruiz-Garcia, J.; Koay, M.S.; Cornelissen, J.J.; Vazquez-Duhalt, R. Chemotherapy pro-drug activation by biocatalytic virus-like nanoparticles containing cytochrome P450. Enzym. Microb. Technol. 2014, 60, 24-31. [CrossRef]

26. Phelps, J.P.; Dang, N.; Rasochova, L. Inactivation and purification of cowpea mosaic virus-like particles displaying peptide antigens from Bacillus anthracis. J. Virol. Methods 2007, 141, 146-153. [CrossRef] [PubMed]

27. Azizgolshani, O.; Garmann, R.F.; Cadena-Nava, R.; Knobler, C.M.; Gelbart, W.M. Reconstituted plant viral capsids can release genes to mammalian cells. Virology 2013, 441, 12-17. [CrossRef]

28. Eiben, S.; Koch, C.; Altintoprak, K.; Southan, A.; Tovar, G.; Laschat, S.; Weiss, I.M.; Wege, C. Plant virus-based materials for biomedical applications: Trends and prospects. Adv. Drug Deliv. Rev. 2019, 145, 96-118. [CrossRef]

29. Lomonossoff, G.P.; Wege, C. TMV Particles: The Journey from Fundamental Studies to Bionanotechnology Applications. Adv. Virus Res. 2018, 102, 149.

30. Gamper, C.; Spenlé, C.; Boscá, S.; Van Der Heyden, M.; Erhardt, M.; Orend, G.; Bagnard, D.; Heinlein, M. Functionalized Tobacco Mosaic Virus Coat Protein Monomers and Oligomers as Nanocarriers for Anti-Cancer Peptides. Cancers 2019, 11, 1609. [CrossRef]

31. Scholthof, K.-B.; Adkins, S.; Czosnek, H.; Palukaitis, P.; Jacquot, E.; Hohn, T.; Hohn, B.; Saunders, K.; Candresse, T.; Ahlquist, P.; et al. Top 10 plant viruses in molecular plant pathology. Mol. Plant Pathol. 2011, 12, 938-954. [CrossRef] [PubMed]

32. Lomonossoff, G.P. So what have plant viruses ever done for virology and molecular biology? Adv. Virus Res. 2018, 100, 145. [PubMed]

33. Gallie, D.R.; Sleat, D.E.; Watts, J.W.; Turner, P.C.; Wilson, T.M.A. The 5'-leader sequence of tobacco mosaic virus RNA enhances the expression of foreign gene transcripts in vitro and in vivo. Nucleic Acids Res. 1987, 15, 3257. [CrossRef] [PubMed]

34. Wilson, T.M.A. Plant viruses: A tool-box for genetic engineering and crop protection. Bioessays 1989, 10, 179. [PubMed]

35. Peyret, H.; Lomonossoff, G.P. When plant virology met Agrobacterium: The rise of the deconstructed clones. Plant Biotechnol. J. 2015, 13, 1121-1135. [CrossRef]

36. Golemboski, D.B.; Lomonossoff, G.P.; Zaitlin, M. Plants transformed with a tobacco mosaic virus nonstructural gene sequence are resistant to the virus. Proc. Natl. Acad. Sci. USA 1990, 87, 6311-6315. [CrossRef]

37. Abel, P.P.; Nelson, R.S.; De, B.; Hoffmann, N.; Rogers, S.G.; Fraley, R.T.; Beachy, R.N. Delay of disease development in transgenic plants that express the tobacco mosaic virus coat protein gene. Science 1986, 232, 738-743. [CrossRef] [PubMed]

38. Fromm, S.; Bharat, T.A.; Jakobi, A.J.; Hagen, W.; Sachse, C. Seeing tobacco mosaic virus through direct electron detectors. J. Struct. Biol. 2015, 189, 87-97. [CrossRef]

39. Sleat, D.; Turner, P.; Finch, J.; Butler, P.; Wilson, T. Packaging of recombinant RNA molecules into pseudovirus particles directed by the origin-of-assembly sequence from tobacco mosaic virus RNA. Virology 1986, 155, 299-308. [CrossRef]

40. Bruckman, M.; Hern, S.; Jiang, K.; Flask, C.A.; Yu, X.; Steinmetz, N.F. Tobacco mosaic virus rods and spheres as supramolecular high-relaxivity MRI contrast agents. J. Mater. Chem. B 2013, 1, 1482-1490. [CrossRef]

41. Fraenkel-Conrat, H.; Williams, R.C. Reconstitution of active tobacco mosaic virus from its inactive protein and nucleic acid components. Proc. Natl. Acad. Sci. USA 1955, 41, 690-698. [CrossRef] [PubMed]

42. Smith, M.L.; Fitzmaurice, W.P.; Turpen, T.H.; Palmer, K.E. Display of Peptides on the Surface of Tobacco Mosaic Virus Particles. Curr. Top. Microbiol. Immunol. 2009, 332, 13-31. [CrossRef]

43. Moore, L.; Hamorsky, K.; Matoba, N. Production of Recombinant Cholera Toxin B Subunit in Nicotiana benthamiana Using GENEWARE $^{\circledR}$ Tobacco Mosaic Virus Vector. Methods Protoc. 2016, 1385, 129-137. [CrossRef]

44. McCormick, A.A.; Reinl, S.J.; Cameron, T.I.; Vojdani, F.; Fronefield, M.; Levy, R.; Tusé, D. Individualized human scFv vaccines produced in plants: Humoral anti-idiotype responses in vaccinated mice confirm relevance to the tumor Ig. J. Immunol. Methods 2003, 278, 95-104. [CrossRef]

45. Kumagai, M.H.; Donson, J.; Dellacioppa, G.R.; Grill, L.K. Rapid, high-level expression of glycosylated rice $\alpha$-amylase in transfected plants by an RNA viral vector. Gene 2000, 245, 169-174. [CrossRef]

46. Giritch, A.; Marillonnet, S.; Engler, C.; van Eldik, G.; Botterman, J.; Klimyuk, V.; Gleba, Y. Rapid high-yield expression of full-size IgG antibodies in plants coinfected with noncompeting viral vectors. Proc. Natl. Acad. Sci. USA 2006, 103, 14701-14706. [CrossRef]

47. Gils, M.; Kandzia, R.; Marillonnet, S.; Klimyuk, V.; Gleba, Y. High-yield production of authentic human growth hormone using a plant virus-based expression system. Plant Biotechnol. J. 2005, 3, 613-620. [CrossRef] [PubMed]

48. Czapar, A.E.; Zheng, Y.; Riddell, I.A.; Shukla, S.; Awuah, S.G.; Lippard, S.J.; Steinmetz, N.F. Tobacco Mosaic Virus Delivery of Phenanthriplatin for Cancer therapy. ACS Nano 2016, 10, 4119-4126. [CrossRef]

49. Sainsbury, F.; Lomonossoff, G.P. Extremely High-Level and Rapid Transient Protein Production in Plants without the Use of Viral Replication. Plant Physiol. 2008, 148, 1212-1218. [CrossRef]

50. Porta, C.; Spall, V.E.; Loveland, J.; Johnson, J.E.; Barker, P.J.; Lomonossoff, G.P. Development of Cowpea Mosaic Virus as a High-Yielding System for the Presentation of Foreign Peptides. Virology 1994, 202, 949-955. [CrossRef]

51. Aljabali, A.A.A.; Sainsbury, F.; Lomonossoff, G.P.; Evans, D.J. Cowpea Mosaic Virus Unmodified Empty Viruslike Particles Loaded with Metal and Metal Oxide. Small 2010, 6, 818-821. [CrossRef]

52. Uhde-Holzem, K.; Schlösser, V.; Viazov, S.; Fischer, R.; Commandeur, U. Immunogenic properties of chimeric potato virus X particles displaying the hepatitis C virus hypervariable region I peptide R9. J. Virol. Methods 2010, 166, 12-20. [CrossRef] 
53. Huang, Z.; Chen, Q.; Hjelm, B.; Arntzen, C.; Mason, H. A DNA replicon system for rapid high-level production of virus-like particles in plants. Biotechnol. Bioeng. 2009, 103, 706-714. [CrossRef] [PubMed]

54. Ibrahim, A.; Odon, V.; Kormelink, R. Plant Viruses in Plant Molecular Pharming: Toward the Use of Enveloped Viruses. Front. Plant Sci. 2019, 10, 803. [CrossRef] [PubMed]

55. Finbloom, J.A.; Han, K.; Aanei, I.L.; Hartman, E.C.; Finley, D.T.; Dedeo, M.T.; Fishman, M.; Downing, K.H.; Francis, M.B. Stable Disk Assemblies of a Tobacco Mosaic Virus Mutant as Nanoscale Scaffolds for Applications in Drug Delivery. Bioconj. Chem. 2016, 27, 2480-2485. [CrossRef] [PubMed]

56. Shukla, S.; Eber, F.J.; Nagarajan, A.S.; DiFranco, N.A.; Schmidt, N.; Wen, A.M.; Eiben, S.; Twyman, R.M.; Wege, C.; Steinmetz, N.F. The Impact of Aspect Ratio on the Biodistribution and Tumor Homing of Rigid Soft-Matter Nanorods. Adv. Healthc. Mater. 2015, 4, 874-882. [CrossRef]

57. Bazzini, A.A.; Hopp, H.E.; Beachy, R.N.; Asurmendi, S. Infection and coaccumulation of tobacco mosaic virus proteins alter microRNA levels, correlating with symptom and plant development. Proc. Natl. Acad. Sci. USA 2007, 104, 12157-12162. [CrossRef] [PubMed]

58. Shukla, S.; Dickmeis, C.; Nagarajan, A.S.; Fischer, R.; Commandeur, U.; Steinmetz, N.F. Molecular farming of fluorescent virus-based nanoparticles for optical imaging in plants, human cells and mouse models. Biomater. Sci. 2014, 2, 784-797. [CrossRef]

59. Wang, Q.; Kaltgrad, E.; Lin, T.; Johnson, J.; Finn, M. Natural Supramolecular Building Blocks: Wild-Type Cowpea Mosaic Virus. Chem. Biol. 2002, 9, 805-811. [CrossRef]

60. Huynh, N.T.; Hesketh, E.L.; Saxena, P.; Meshcheriakova, Y.; Ku, Y.-C.; Hoang, L.T.; Johnson, J.E.; Ranson, N.; Lomonossoff, G.P.; Reddy, V.S. Crystal Structure and Proteomics Analysis of Empty Virus-like Particles of Cowpea Mosaic Virus. Structure 2016, 24, 567-575. [CrossRef]

61. Sokullu, E.; Abyaneh, H.S.; Gauthier, M.A. Plant/Bacterial Virus-Based Drug Discovery, Drug Delivery, and Therapeutics. Pharmaceutics 2019, 11, 211. [CrossRef]

62. Koch, C.; Poghossian, A.; Schöning, M.J.; Wege, C. Penicillin Detection by Tobacco Mosaic Virus-Assisted Colorimetric Biosensors. Nanotheranostics 2018, 2, 184-196. [CrossRef]

63. Poghossian, A.; Jablonski, M.; Koch, C.; Bronder, T.S.; Rolka, D.; Wege, C.; Schoning, M.J. Field-effect biosensor using virus particles as scaffolds for enzyme immobilization. Biosens. Bioelectron. 2018, 110, 168. [CrossRef] [PubMed]

64. Koch, C.; Wabbel, K.; Eber, F.J.; Krolla-Sidenstein, P.; Azucena, C.; Gliemann, H.; Eiben, S.; Geiger, F.; Wege, C. Modified TMV particles as beneficial scaffolds to present sensor enzymes. Front. Plant Sci. 2015, 6, 1137. [CrossRef]

65. Bäcker, M.; Koch, C.; Eiben, S.; Geiger, F.; Eber, F.; Gliemann, H.; Poghossian, A.; Wege, C.; Schoening, M.J. Tobacco mosaic virus as enzyme nanocarrier for electrochemical biosensors. Sens. Actuators B Chem. 2017, 238, 716-722. [CrossRef]

66. Tiu, B.D.B.; Kernan, D.L.; Tiu, S.B.; Wen, A.M.; Zheng, Y.; Pokorski, J.K.; Advincula, R.C.; Steinmetz, N.F. Electrostatic layer-bylayer construction offibrous TMV biofilms. Nanoscale 2017, 9, 1580. [CrossRef] [PubMed]

67. Kaur, G.; Wang, C.; Sun, J.; Wang, Q. The synergistic effects of multivalent ligand display and nanotopography on osteogenic differentiation of rat bone marrow stem cells. Biomaterials 2010, 31, 5813-5824. [CrossRef] [PubMed]

68. Sitasuwan, P.; Lee, L.A.; Li, K.; Nguyen, H.G.; Wang, Q. RGD-conjugated rod-like viral nanoparticles on 2D scaffold improve bone differentiation of mesenchymal stem cells. Front. Chem. 2014, 2, 31. [CrossRef] [PubMed]

69. Wu, L.; Zang, J.; Lee, L.A.; Niu, Z.; Horvatha, G.C.; Braxtona, V.; Wibowo, A.C.; Bruckman, M.A.; Ghoshroy, S.; Loye, H.-C.Z.; et al. Electrospinning fabrication, structural and mechanical characterization of rod-like virus-based composite nanofibers. J. Mater. Chem. 2011, 21, 8550-8557. [CrossRef]

70. Beachy, R.N. Coat-protein-mediated resistance to tobacco mosaic virus: Discovery mechanisms and exploitation. Philos. Trans. R. Soc. B Biol. Sci. 1999, 354, 659-664. [CrossRef]

71. Mascia, T.; Nigro, F.; Abdallah, A.; Ferrara, M.; De Stradis, A.; Faedda, R.; Palukaitis, P.; Gallitelli, D. Gene silencing and gene expression in phytopathogenic fungi using a plant virus vector. Proc. Natl. Acad. Sci. USA 2014, 111, 4291-4296. [CrossRef]

72. Shukla, S.; Ablack, A.L.; Wen, A.M.; Lee, K.L.; Lewis, J.D.; Steinmetz, N.F. Increased Tumor Homing and Tissue Penetration of the Filamentous Plant Viral Nanoparticle Potato virus X. Mol. Pharm. 2013, 10, 33-42. [CrossRef]

73. Lee, K.L.; Hubbard, L.C.; Hern, S.; Yildiz, I.; Gratzl, M.; Steinmetz, N.F. Shape matters: The diffusion rates of TMV rods and CPMV icosahedrons in a spheroid model of extracellular matrix are distinct. Biomater. Sci. 2013, 1, 581-588. [CrossRef] [PubMed]

74. Rong, J.; Niu, Z.; Lee, L.A.; Wang, Q. Self-assembly of viral particles. Curr. Opin. Colloid Interface Sci. 2011, 16, 441-450. [CrossRef]

75. Park, J.; Gao, H.; Wang, Y.; Hu, H.; Simon, D.I.; Steinmetz, N.F. S100A9-targeted tobacco mosaic virus nanoparticles exhibit high specificity toward atherosclerotic lesions in ApoE- / - mice. J. Mater. Chem. B 2019, 7, 1842-1846. [CrossRef]

76. Grasso, S.; Santi, L. Viral nanoparticles as macromolecular devices for new therapeutic and pharmaceutical approaches. Int. J. Physiol. Pathophysiol. Pharmacol. 2010, 2, 161-178.

77. Chapman, S.; Faulkner, C.; Kaiserli, E.; Garcia-Mata, C.; Savenkov, E.I.; Roberts, A.G.; Oparka, K.J.; Christie, J.M. The photoreversible fluorescent protein iLOV outperforms GFP as a reporter of plant virus infection. Proc. Natl. Acad. Sci. USA 2008, 105, 20038-20043. [CrossRef]

78. Wu, L.; Jiang, L.; Zhou, Z.; Fan, J.; Zhang, Q.; Zhu, H.; Han, Q.; Xu, Z. Expression of foot-and-mouth disease virus epitopes in tobacco by a tobacco mosaic virus-based vector. Vaccine 2003, 21, 4390. [CrossRef] 
79. Koo, M.; Bendahmane, M.; Lettieri, G.A.; Paoletti, A.D.; Lane, T.E.; Fitchen, J.H.; Buchmeier, M.J.; Beachy, R.N. Protective immunity against murine hepatitis virus (MHV) induced by intranasal or subcutaneous administration of hybrids of tobacco mosaic virus that carries an MHV epitope. Proc. Natl. Acad. Sci. USA 1999, 96, 7774-7779. [CrossRef] [PubMed]

80. Staczek, J.; Bendahmane, M.; Gilleland, L.B.; Beachy, R.N.; Gilleland, H. Immunization with a chimeric tobacco mosaic virus containing an epitope of outer membrane protein F of Pseudomonas aeruginosa provides protection against challenge with $\mathrm{P}$. aeruginosa. Vaccine 2000, 18, 2266-2274. [CrossRef]

81. Pitek, A.S.; Park, J.; Wang, Y.; Gao, H.; Hu, H.; Simon, D.I.; Steinmetz, N.F. Delivery of thrombolytic therapy using rod-shaped plant viral nanoparticles decreases the risk of hemorrhage. Nanoscale 2018, 10, 16547-16555. [CrossRef]

82. Yin, Z.; Nguyen, H.G.; Chowdhury, S.; Bentley, P.; Bruckman, M.A.; Miermont, A.; Gildersleeve, J.C.; Wang, Q.; Huang, X. Tobacco mosaic virus as a new carrier for tumor associated carbohydrate antigens. Bioconjug. Chem. 2012, 23, 1694-1703. [CrossRef]

83. Finbloom, J.A.; Aanei, I.L.; Bernard, J.M.; Klass, S.H.; Elledge, S.K.; Han, K.; Ozawa, T.; Nicolaides, T.P.; Berger, M.S.; Francis, M.B. Evaluation of Three Morphologically Distinct Virus-Like Particles as Nanocarriers for Convection-Enhanced Drug Delivery to Glioblastoma. Nanomaterials 2018, 8, 1007. [CrossRef]

84. Pitek, A.S.; Hu, H.; Shukla, S.; Steinmetz, N.F. Cancer Theranostic Applications of Albumin-Coated Tobacco Mosaic Virus Nanoparticles. ACS Appl. Mater. Interfaces 2018, 10, 39468-39477. [CrossRef]

85. Franke, C.E.; Czapar, A.E.; Patel, R.; Steinmetz, N.F. Tobacco Mosaic Virus-Delivered Cisplatin Restores Efficacy in PlatinumResistant Ovarian Cancer Cells. Mol. Pharm. 2017, 15, 2922-2931. [CrossRef]

86. Vernekar, A.; Berger, G.; Czapar, A.E.; Veliz, F.A.; Wang, D.I.; Steinmetz, N.F.; Lippard, S.J. Speciation of Phenanthriplatin and Its Analogs in the Core of Tobacco Mosaic Virus. J. Am. Chem. Soc. 2018, 140, 4279-4287. [CrossRef]

87. Liu, X.; Liu, B.; Gao, S.; Wang, Z.; Tian, Y.; Wu, M.; Jiang, S.; Niu, Z. Glyco-decorated tobacco mosaic virus as a vector for cisplatin delivery. J. Mater. Chem. B 2017, 5, 2078-2085. [CrossRef] [PubMed]

88. Gao, S.; Liu, X.; Wang, Z.; Jiang, S.; Wu, M.; Tian, Y.; Niu, Z. Fluorous interaction induced self-assembly of tobacco mosaic virus coat protein for cisplatin delivery. Nanoscale 2018, 10, 11732-11736. [CrossRef] [PubMed]

89. Lin, R.D.; Steinmetz, N.F. Tobacco mosaic virus delivery of mitoxantrone for cancer therapy. Nanoscale 2018, 10, 16307-16313. [CrossRef] [PubMed]

90. Kernan, D.L.; Wen, A.M.; Pitek, A.S.; Steinmetz, N.F. Featured Article: Delivery of chemotherapeutic vcMMAE using tobacco mosaic virus nanoparticles. Exp. Biol. Med. 2017, 242, 1405-1411. [CrossRef] [PubMed]

91. Tian, Y.; Zhou, M.; Shi, H.; Gao, S.; Xie, G.; Zhu, M.; Wu, M.; Chen, J.; Niu, Z. Integration of Cell-Penetrating Peptides with Rod-like Bionanoparticles: Virus-Inspired Gene-Silencing Technology. Nano Lett. 2018, 18, 5453-5460. [CrossRef] [PubMed]

92. Chariou, P.L.; Wang, L.; Desai, C.; Park, J.; Robbins, L.K.; von Recum, H.A.; Ghiladi, R.A.; Steinmetz, N.F. Let There Be Light: Targeted Photodynamic Therapy Using High Aspect Ratio Plant Viral Nanoparticles. Macromol. Biosci. 2019, 19 , e1800407. [CrossRef] [PubMed]

93. Luzuriaga, M.A.; Welch, R.P.; Dharmarwardana, M.; Benjamin, C.E.; Li, S.; Shahrivarkevishahi, A.; Popal, S.; Tuong, L.H.; Creswell, C.T.; Gassensmith, J.J. Enhanced Stability and Controlled Delivery of MOF-Encapsulated Vaccines and Their Immunogenic Response In Vivo. ACS Appl. Mater. Interfaces 2019, 11, 9740-9746. [CrossRef] [PubMed]

94. Bruckman, M.; Jiang, K.; Simpson, E.J.; Randolph, L.N.; Luyt, L.; Yu, X.; Steinmetz, N.F. Dual-Modal Magnetic Resonance and Fluorescence Imaging of Atherosclerotic Plaques in Vivo Using VCAM-1 Targeted Tobacco Mosaic Virus. Nano Lett. 2014, 14, 1551-1558. [CrossRef]

95. Dharmarwardana, M.; Martins, A.F.; Chen, Z.; Palacios, P.M.; Nowak, C.M.; Welch, R.P.; Li, S.; Luzuriaga, M.A.; Bleris, L.; Pierce, B.S.; et al. Nitroxyl Modified Tobacco Mosaic Virus as a Metal-Free High-Relaxivity MRI and EPR Active Superoxide Sensor. Mol. Pharm. 2018, 15, 2973-2983. [CrossRef]

96. Lee, H.; Shahrivarkevishahi, A.; Lumata, J.L.; Luzuriaga, M.A.; Hagge, L.M.; Benjamin, C.E.; Brohlin, O.R.; Parish, C.R.; Firouzi, H.R.; Nielsen, S.O.; et al. Supramolecular and biomacromolecular enhancement of metal-free magnetic resonance imaging contrast agents. Chem. Sci. 2020, 11, 2045-2050. [CrossRef]

97. Wang, Y.; Black, K.C.L.; Luehmann, H.; Li, W.; Zhang, Y.S.; Cai, X.; Wan, D.; Liu, S.-Y.; Li, M.; Kim, P.; et al. Comparison Study of Gold Nanohexapods, Nanorods, and Nanocages for Photothermal Cancer Treatment. ACS Nano 2013, 7, 2068-2077. [CrossRef] [PubMed]

98. Vankayala, R.; Huang, Y.-K.; Kalluru, P.; Chiang, C.-S.; Hwang, K.C. First Demonstration of Gold Nanorods-Mediated Photodynamic Therapeutic Destruction of Tumors via Near Infra-Red Light Activation. Small 2014, 10, 1612-1622. [CrossRef] [PubMed]

99. Scholthof, K.-B.G. Tobaccomosaic Virus: A Model System for Plant Biology. Annu. Rev. Phytopathol. 2004, 42, 13-34. [CrossRef]

100. Hu, H.; Yang, Q.; Baroni, S.; Yang, H.; Aime, S.; Steinmetz, N.F. Polydopamine-decorated tobacco mosaic virus for photoacous$\mathrm{tic} /$ magnetic resonance bimodal imaging and photothermal cancer therapy. Nanoscale 2019, 11, 9760-9768. [CrossRef]

101. Yu, X.-Q.; Jia, J.-L.; Zhang, C.-L.; Li, X.-D.; Wang, Y.-J. Phylogenetic analyses of an isolate obtained from potato in 1985 revealed potato virus $X$ was introduced to China via multiple events. Virus Genes 2010, 40, 447-451. [CrossRef]

102. Wang, Y.; Cong, Q.-Q.; Lan, Y.-F.; Geng, C.; Li, X.-D.; Liang, Y.-C.; Yang, Z.-Y.; Zhu, X.-P.; Li, X.-D. Development of new potato virus $X$-based vectors for gene over-expression and gene silencing assay. Virus Res. 2014, 191, 62-69. [CrossRef] [PubMed]

103. Lacomme, C.; Chapman, S. Use of potato virus X (PVX)-based vectors for geneexpression and virus-induced gene silencing (VIGS). Curr. Protoc. Microbiol. 2008. [CrossRef] [PubMed] 
104. Plchova, H.; Moravec, T.; Hoffmeisterova, H.; Folwarczna, J.; Čeřovská, N. Expression of Human papillomavirus 16 E7ggg oncoprotein on N- and C-terminus of Potato virus X coat protein in bacterial and plant cells. Protein Expr. Purif. 2011, 77, 146-152. [CrossRef] [PubMed]

105. Hefferon, K. Plant Virus Expression Vectors: A Powerhouse for Global Health. Biomedicines 2017, 5, 44. [CrossRef] [PubMed]

106. Uhde-Holzem, K.; McBurney, M.; Tiu, B.D.; Advincula, R.C.; Fischer, R.; Commandeur, U.; Steinmetz, N.F. Production of Immunoabsorbent Nanoparticles by Displaying Single-Domain Protein A on Potato Virus X. Macromol. Biosci. 2016, 16, $231-241$. [CrossRef] [PubMed]

107. Yang, L.; Biswas, M.E.; Chen, P. Study of Binding between Protein A and Immunoglobulin G Using a Surface Tension Probe. Biophys. J. 2003, 84, 509-522. [CrossRef]

108. Arkhipenko, M.V.; Petrova, E.K.; Nikitin, N.A.; Protopopova, A.D.; Dubrovin, E.V.; Yaminskii, I.V.; Rodionova, N.P.; Karpova, O.; Atabekov, J.G.; Center, A.T. Characteristics of Artificial Virus-like Particles Assembled in vitro from Potato Virus X Coat Protein and Foreign Viral RNAs. Acta Nat. 2011, 3. [CrossRef]

109. Tyulkina, L.G.; Skurat, E.V.; Frolova, O.Y.; Komarova, T.V.; Karger, E.M.; Atabekov, I.G. New Viral Vector for Superproduction of Epitopes of Vaccine Proteins in Plants. Acta Nat. 2011, 3, 11. [CrossRef]

110. Shukla, S.; DiFranco, N.A.; Wen, A.M.; Commandeur, U.; Steinmetz, N.F. To Target or Not to Target: Active vs. Passive Tumor Homing of Filamentous Nanoparticles Based on Potato virus X. Cell. Mol. Bioeng. 2015, 8, 433-444. [CrossRef]

111. Röder, J.; Dickmeis, C.; Fischer, R.; Commandeur, U. Systemic infection of nicotiana benthamianawith potato virus X nanoparticles presenting a fluorescent iLOV polypeptide fused directly to the coat protein. Biomed. Res. Int. 2018, e932867. [CrossRef]

112. Shukla, S.; Dickmeis, C.; Fischer, R.; Commandeur, U.; Steinmetz, N.F. In Planta Production of Fluorescent Filamentous Plant Virus-Based Nanoparticles. Methods Mol. Biol. 2018, 1776, 61-84. [CrossRef]

113. Li, P.; Jing, C.; Ren, H.; Jia, Z.; Ghanem, H.; Wu, G.; Li, M.; Qing, L.; Li, P.; Jing, C.; et al. Analysis of Pathogenicity and Virulence Factors of Ageratum leaf curl Sichuan virus. Front. Plant Sci. 2020, 11. [CrossRef]

114. Shi, J.; Zhu, Y.; Li, M.; Ma, Y.; Liu, H.; Zhang, P.; Fang, D.; Guo, Y.; Xu, P.; Qiao, Y. Establishment of a novel virus-induced virulence effector assay for the identification of virulence effectors of plant pathogens using a PVX-based expression vector. Mol. Plant Pathol. 2020, 21, 1654-1661. [CrossRef]

115. Wang, X.; Luo, C.; Xu, Y.; Zhang, C.; Bao, M.; Dou, J.; Wang, Q.; Cheng, Y. Expression of the p24 silencing suppressor of Grapevine leafroll-associated virus 2 from Potato virus $X$ or Barley stripe mosaic virus vector elicits hypersensitive responses in Nicotiana benthamiana. Plant Physiol Biochem. 2019, 142, 34-42. [CrossRef]

116. Wieczorek, P.; Wrzesińska, B.; Frąckowiak, P.; Przybylska, A.; Obrępalska-Stęplowska, A. Contribution of Tomato torrado virus Vp26 coat protein subunit to systemic necrosis induction and virus infectivity in Solanum lycopersicum. Virol. J. 2019, 16, 9. [CrossRef] [PubMed]

117. Faivre-Rampant, O.; Gilroy, E.M.; Hrubikova, K.; Hein, I.; Millam, S.; Loake, G.J.; Birch, P.; Taylor, M.; Lacomme, C. Potato virus X-induced gene silencing in leavesand tubers of potato. Plant Physiol. 2004, 134, 1308-1316. [CrossRef] [PubMed]

118. Kopertekh, L.; Meyer, T.; Freyer, C.; Hust, M. Transient plant production of Salmonella Typhimurium diagnostic antibodies. Biotechnol. Rep. 2018, 20, e00314. [CrossRef]

119. Demurtas, O.C.; Massa, S.; Illiano, E.; De Martinis, D.; Chan, P.; Di Bonito, P.; Franconi, R. Antigen Production in Plant to Tackle Infectious Diseases Flare Up: The Case of SARS. Front. Plant Sci. 2016, 7, 54. [CrossRef]

120. Mardanova, E.S.; Kotlyarov, R.Y.; Kuprianov, V.V.; Stepanova, L.A.; Tsybalova, L.M.; Lomonosoff, G.P.; Ravin, N.V. Rapid high-yield expression of a candidate influenza vaccine based on the ectodomain of M2 protein linked to flagellin in plants using viral vectors. BMC Biotechnol. 2015, 15, 42. [CrossRef] [PubMed]

121. Mohammadzadeh, S.; Roohvand, F.; Memarnejadian, A.; Jafari, A.; Ajdary, S.; Salmanian, A.H.; Ehsani, P. Co-expression of hepatitis $C$ virus polytope-HBsAg and p19-silencing suppressor protein in tobacco leaves. Pharm. Biol. 2016, 54, 465-473. [CrossRef]

122. Khezri, G.; Rouz, B.B.K.; Ofoghi, H.; Davarpanah, S.J. Heterologous expression of biologically active Mambalgin-1 peptide as a new potential anticancer, using a PVX-based viral vector in Nicotiana benthamiana. Plant Cell Tissue Organ Cult. 2020, 142, 1-11 [CrossRef] [PubMed]

123. Esfandiari, N.; Arzanani, M.K.; Soleimani, M.; Kohi-Habibi, M.; Svendsen, W.E. A new application of plant virus nanoparticles as drug delivery in breast cancer. Tumor Biol. 2016, 37, 1229-1236. [CrossRef] [PubMed]

124. Demurtas, O.C.; Massa, S.; Ferrante, P.; Venuti, A.; Franconi, R.; Giuliano, G. A Chlamydomonas-Derived Human Papillomavirus 16 E7 Vaccine Induces Specific Tumor Protection. PLoS ONE 2013, 8, e61473. [CrossRef]

125. Le, D.H.T.; Lee, K.L.; Shukla, S.; Commandeur, U.; Steinmetz, N.F. Potato virus X, a filamentous plant viral nanoparticle for doxorubicin delivery in cancer therapy. Nanoscale 2017, 9, 2348-2357. [CrossRef] [PubMed]

126. Lee, K.L.; Murray, A.A.; Le, D.H.T.; Sheen, M.R.; Shukla, S.; Commandeur, U.; Fiering, S.; Steinmetz, N.F. Combination of Plant Virus Nanoparticle-Based in Situ Vaccination with Chemotherapy Potentiates Antitumor Response. Nano Lett. 2017, 17, 4019-4028. [CrossRef] [PubMed]

127. Le, D.H.T.; Commandeur, U.; Steinmetz, N.F. Presentation and Delivery of Tumor Necrosis Factor-Related Apoptosis-Inducing Ligand via Elongated Plant Viral Nanoparticle Enhances Antitumor Efficacy. ACS Nano 2019, 13, 2501-2510. [CrossRef] 
128. Jobsri, J.; Allen, A.; Rajagopal, D.; Shipton, M.; Kanyuka, K.; Lomonossoff, G.P.; Ottensmeier, C.; Diebold, S.S.; Stevenson, F.; Savelyeva, N. Plant Virus Particles Carrying Tumour Antigen Activate TLR7 and Induce High Levels of Protective Antibody. PLoS ONE 2015, 10, e0118096. [CrossRef] [PubMed]

129. Kruse, I.; Peyret, H.; Saxena, P.; Lomonossoff, G.P. Encapsidation of Viral RNA in Picornavirales: Studies on Cowpea Mosaic Virus Demonstrate Dependence on Viral Replication. J. Virol. 2019, 93, e01520-18. [CrossRef] [PubMed]

130. Liu, L.; Cañizares, M.; Monger, W.; Perrin, Y.; Tsakiris, E.; Porta, C.; Shariat, N.; Nicholson, L.; Lomonossoff, G.P. Cowpea mosaic virus-based systems for the production of antigens and antibodies in plants. Vaccine 2005, 23, 1788-1792. [CrossRef]

131. Sainsbury, F.; Cañizares, M.C.; Lomonossoff, G.P. Cowpea mosaicVirus: The Plant Virus-Based Biotechnology Workhorse. Annu. Rev. Phytopathol. 2010, 48, 437-455. [CrossRef]

132. Sainsbury, F.; Sack, M.; Stadlmann, J.; Quendler, H.; Fischer, R.; Lomonossoff, G.P. Rapid Transient Production in Plants by Replicating and Non-Replicating Vectors Yields High Quality Functional Anti-HIV Antibody. PLoS ONE 2010, 5, e13976. [CrossRef]

133. Meshcheriakova, Y.; Durrant, A.; Hesketh, E.L.; Ranson, N.; Lomonossoff, G.P. Combining high-resolution cryo-electron microscopy and mutagenesis to develop cowpea mosaic virus for bionanotechnology. Biochem. Soc. Trans. 2017, 45, 1263-1269. [CrossRef] [PubMed]

134. Wang, C.; Beiss, V.; Steinmetz, N.F. Cowpea Mosaic Virus Nanoparticles and Empty Virus-Like Particles Show Distinct but Overlapping Immunostimulatory Properties. J. Virol. 2019, 93. [CrossRef] [PubMed]

135. Dent, M.; Matoba, N. Cancer biologics made in plants. Curr. Opin. Biotechnol. 2020, 61, 82-88. [CrossRef] [PubMed]

136. Steinmetz, N.F.; Cho, C.-F.; Ablack, A.; Lewis, J.D.; Manchester, M. Cowpea mosaic virus nanoparticles target surface vimentin on cancer cells. Nanomedicine 2011, 6, 351-364. [CrossRef]

137. Lizotte, P.; Wen, A.M.; Sheen, M.R.; Fields, J.; Rojanasopondist, P.; Steinmetz, N.F.; Fiering, S. In situ vaccination with cowpea mosaic virus nanoparticles suppresses metastatic cancer. Nat. Nanotechnol. 2016, 11, 295-303. [CrossRef]

138. Patel, R.; Czapar, A.E.; Fiering, S.; Oleinick, N.L.; Steinmetz, N.F. Radiation Therapy Combined with Cowpea Mosaic Virus Nanoparticle in Situ Vaccination Initiates Immune-Mediated Tumor Regression. ACS Omega 2018, 3, 3702-3707. [CrossRef]

139. Wang, C.; Steinmetz, N.F. CD47 Blockade and Cowpea Mosaic Virus Nanoparticle In Situ Vaccination Triggers Phagocytosis and Tumor Killing. Adv. Healthc. Mater. 2019, 8, e1801288. [CrossRef] [PubMed]

140. Cai, H.; Wang, C.; Shukla, S.; Steinmetz, N.F. Cowpea Mosaic Virus Immunotherapy Combined with Cyclophosphamide Reduces Breast Cancer Tumor Burden and Inhibits Lung Metastasis. Adv. Sci. 2019, 6, 1802281. [CrossRef]

141. Albakri, M.; Veliz, F.A.; Fiering, S.N.; Steinmetz, N.F.; Sieg, S.F. Endosomal toll-like receptors play a key role in activation of primary human monocytes by cowpea mosaic virus. Immunology 2019, 159, 183-192. [CrossRef] [PubMed]

142. Shukla, S.; Wang, C.; Beiss, V.; Cai, H.; Washington, T., II; Murray, A.A.; Gong, X.; Zhao, Z.; Masarapu, H.; Zlotnick, A.; et al. The unique potency of Cowpea mosaic virus (CPMV) in situ cancer vaccine. Biomater. Sci. 2020, 8, 5489-5503. [CrossRef] [PubMed]

143. Biddlecome, A.; Habte, H.H.; McGrath, K.M.; Sambanthamoorthy, S.; Wurm, M.; Sykora, M.M.; Knobler, C.M.; Lorenz, I.C.; Lasaro, M.; Elbers, K.; et al. Delivery of self-amplifying RNA vaccines in in vitro reconstituted virus-like particles. PLoS ONE 2019, 14, e0215031. [CrossRef]

144. Cai, H.; Shukla, S.; Steinmetz, N.F. The Antitumor Efficacy of CpG Oligonucleotides is Improved by Encapsulation in Plant Virus-Like Particles. Adv. Funct. Mater. 2020, 30, 1908743. [CrossRef] [PubMed]

145. Koyani, R.D.; Pérez-Robles, J.; Cadena-Nava, R.D.; Vazquez-Duhalt, R. Biomaterial-based nanoreactors, an alternative for enzyme delivery. Nanotechnol. Rev. 2017, 6, 405-419. [CrossRef]

146. Strable, E.; Finn, M.G. Chemical Modification of Viruses and Virus-Like Particles. In Viruses and Nanotechnology; Manchester, M., Steinmetz, N.F., Eds.; Springer: Berlin/Heidelberg, Germany, 2009; pp. 1-21. [CrossRef]

147. Diamos, A.G.; Mason, H.S. High-level expression and enrichment of norovirus virus-like particles in plants using modified geminiviral vectors. Protein Expr. Purif. 2018, 151, 86-92. [CrossRef] [PubMed]

148. Rybicki, E.P.; Martin, D.P. Virus-Derived ssDNA Vectors for the Expression of Foreign Proteins in Plants. Curr. Top. Microbiol. Immunol. 2011, 375, 19-45. [CrossRef]

149. Hefferon, K.L. DNA Virus Vectors for Vaccine Production in Plants: Spotlight on Geminiviruses. Vaccines 2014, 2, 642-653. [CrossRef]

150. Dickey, A.; Wang, N.; Cooper, E.; Tull, L.; Breedlove, D.; Mason, H.; Liu, D.; Wang, K.Y. Transient Expression of Lumbrokinase (PI239) in Tobacco (Nicotiana tabacum) Using a Geminivirus-Based Single Replicon System Dissolves Fibrin and Blood Clots. Evid. Based Complement. Altern. Med. 2017, 2017, 1-9. [CrossRef]

151. Bañuelos-Hernández, B.; Monreal-Escalante, E.; Gonzalez-Ortega, O.; Angulo, C.; Rosales-Mendoza, S. Algevir: An Expression System for Microalgae Based on Viral Vectors. Front. Microbiol. 2017, 8, 1100. [CrossRef]

152. Lozano-Durán, R. Geminiviruses for biotechnology: The art of parasite taming. New Phytol. 2016, 210, 58-64. [CrossRef] [PubMed]

153. Yang, Q.-Y.; Ding, B.; Zhou, X.-P. Geminiviruses and their application in biotechnology. J. Integr. Agric. 2017, 16, 2761-2771. [CrossRef]

154. Diamos, A.G.; Pardhe, M.D.; Sun, H.; Hunter, J.G.L.; Kilbourne, J.; Chen, Q.; Mason, H.S. A Highly Expressing, Soluble, and Stable Plant-Made IgG Fusion Vaccine Strategy Enhances Antigen Immunogenicity in Mice Without Adjuvant. Front. Immunol. 2020, 11, 576012. [CrossRef] [PubMed] 
155. Diamos, A.G.; Pardhe, M.D.; Sun, H.; Hunter, J.G.; Mor, T.; Meador, L.; Kilbourne, J.; Chen, Q.; Mason, H.S. Codelivery of improved immune complex and virus-like particle vaccines containing Zika virus envelope domain III synergistically enhances immunogenicity. Vaccine 2020, 38, 3455-3463. [CrossRef]

156. Čermák, T.; Curtin, S.J.; Gil-Humanes, J.; Čegan, R.; Kono, T.J.Y.; Konečná, E.; Belanto, J.J.; Starker, C.G.; Mathre, J.W.; Greenstein, R.L.; et al. A Multipurpose Toolkit to Enable Advanced Genome Engineering in Plants. Plant Cell. 2017, 29, $1196-1217$. [CrossRef]

157. Zhang, T.; Zheng, Q.; Yi, X.; An, H.; Zhao, Y.; Ma, S.; Zhou, G. Establishing RNA virus resistance in plants by harnessing CRISPR immune system. Plant Biotechnol. J. 2018, 16, 1415-1423. [CrossRef]

158. Ariga, H.; Toki, S.; Ishibashi, K. Potato Virus X Vector-Mediated DNA-Free Genome Editing in Plants. Plant Cell Physiol. 2020, 61, 1946-1953. [CrossRef]

159. Ludman, M.; Burgyán, J.; Fátyol, K. Crispr/Cas9 Mediated Inactivation of Argonaute 2 Reveals its Differential Involvement in Antiviral Responses. Sci. Rep. 2017, 7, 1-12. [CrossRef]

160. Brisson, N.; Paszkowski, J.; Penswick, J.R.; Gronenborn, B.; Potrykus, I.; Hohn, T.M. Expression of a bacterial gene in plants by using a viral vector. Nat. Cell Biol. 1984, 310, 511-514. [CrossRef]

161. French, R.; Janda, M.; Ahlquist, P. Bacterial Gene Inserted in an Engineered RNA Virus: Efficient Expression in Monocotyledonous Plant Cells. Science 1986, 231, 1294-1297. [CrossRef]

162. Palmer, K.; Gleba, Y. Plant Viral Vectors. Curr. Top. Microbiol. Immunol. 2014, 375, 1-194. [CrossRef]

163. Baulcombe, D.; Chapman, S.; Cruz, S.S. Jellyfish green fluorescent protein as a reporter for virus infections. Plant J. 1995, 7, 1045-1053. [CrossRef]

164. Zhang, H.; Wang, L.; Hunter, D.; Voogd, C.; Joyce, N.; Davies, K. A Narcissus mosaic viral vector system for protein expression and flavonoid production. Plant Methods 2013, 9, 28. [CrossRef] [PubMed]

165. Takamatsu, N.; Ishikawa, M.; Meshi, T.; Okada, Y. Expression of bacterial chloramphenicol acetyltransferase gene in tobacco plants mediated by TMV-RNA. EMBO J. 1987, 6, 307-311. [CrossRef] [PubMed]

166. Yusibov, V.; Shivprasad, S.; Turpen, T.H.; Dawson, W.; Koprowski, H. Plant Viral Vectors Based on Tobamoviruses. Plant Biotechnol. 2000, 240, 81-94. [CrossRef]

167. Jarugula, S.; Charlesworth, S.R.; Qu, F.; Stewart, L.R. Soil-borne wheat mosaic virus infectious clone and manipulation for gene-carrying capacity. Arch. Virol. 2016, 161, 2291-2297. [CrossRef] [PubMed]

168. Lellis, A.D.; Kasschau, K.D.; Whitham, S.A.; Carrington, J.C. Loss-ofsusceptibility mutants of Arabidopsis thaliana reveal an essential role for eIF (iso)4E during potyvirus infection. Curr. Biol. 2002, 12, 1046-1051. [CrossRef]

169. Majer, E.; Navarro, J.-A.; Daròs, J.-A. A potyvirus vector efficiently targets recombinant proteins to chloroplasts, mitochondria and nuclei in plant cells when expressed at the amino terminus of the polyprotein. Biotechnol. J. 2015, 10, 1792-1802. [CrossRef]

170. Seo, J.-K.; Choi, H.-S.; Kim, K.-H. Engineering of soybean mosaic virus as a versatile tool for studying protein-protein interactions in soybean. Sci. Rep. 2016, 6, 22436. [CrossRef]

171. Stanley, J. Geminiviruses: Plant viral vectors. Curr. Opin. Genet. Dev. 1993, 3, 91-96. [CrossRef]

172. Sainsbury, F.; Lavoie, P.O.; D'Aoust, M.A.; Vezina, L.P.; Lomonossoff, G.P. Expression of multiple proteins using full-length and deleted versions of Cowpea mosaic virus RNA-2. Plant Biotechnol. J. 2008, 6, 82-92. [CrossRef]

173. Zhang, C.; Bradshaw, J.D.; Whitham, S.A.; Hill, J.H. The Development of an Efficient Multipurpose Bean Pod Mottle Virus Viral Vector Set for Foreign Gene Expression and RNA Silencing. Plant Physiol. 2010, 153, 52-65. [CrossRef]

174. Zhou, B.; Zhang, Y.; Wang, X.-B.; Dong, J.; Wang, B.; Han, C.; Yu, J.; Li, D. Oral administration of plant-based rotavirus VP6 induces antigen-specific IgAs, IgGs and passive protection in mice. Vaccine 2010, 28, 6021-6027. [CrossRef]

175. Bouton, C.; King, R.C.; Chen, H.; Azhakanandam, K.; Bieri, S.; Hammond-Kosack, K.E.; Kanyuka, K. Foxtail mosaic virus: A Viral Vector for Protein Expression in Cereals. Plant Physiol. 2018, 177, 1352-1367. [CrossRef]

176. Cheuk, A.; Houde, M. A New Barley Stripe Mosaic Virus Allows Large Protein Overexpression for Rapid Function Analysis. Plant Physiol. 2018, 176, 1919-1931. [CrossRef] [PubMed]

177. Lee, W.-S.; Hammond-Kosack, K.; Kanyuka, K. Barley Stripe Mosaic Virus-Mediated Tools for Investigating Gene Function in Cereal Plants and Their Pathogens: Virus-Induced Gene Silencing, Host-Mediated Gene Silencing, and Virus-Mediated Overexpression of Heterologous Protein. Plant Physiol. 2012, 160, 582-590. [CrossRef] [PubMed]

178. Yuan, C.; Li, C.; Yan, L.; Jackson, A.O.; Liu, Z.; Han, C.; Yu, J.; Li, D. A High Throughput Barley Stripe Mosaic Virus Vector for Virus Induced Gene Silencing in Monocots and Dicots. PLoS ONE 2011, 6, e26468. [CrossRef] [PubMed]

179. Choi, I.-R.; Stenger, D.C.; Morris, T.J.; French, R. A plant virus vector for systemic expression of foreign genes in cereals. Plant J. 2000, 23, 547-555. [CrossRef] [PubMed]

180. Elzoghby, A.; Samy, W.; Elgindy, N.A. Protein-based nanocarriers as promising drug and gene delivery systems. J. Control. Release 2012, 161, 38-49. [CrossRef] [PubMed]

181. Ma, Y.; Nolte, R.; Cornelissen, J.J. Virus-based nanocarriers for drug delivery. Adv. Drug Deliv. Rev. 2012, 64, 811-825. [CrossRef]

182. Ferrer-Miralles, N.; Rodríguez-Carmona, E.; Corchero, J.L.; García-Fruitós, E.; Vázquez, E.; Villaverde, A. Engineering protein self-assembling in protein-based nanomedicines for drug delivery and gene therapy. Crit. Rev. Biotechnol. 2015, 35, $209-221$. [CrossRef] [PubMed] 